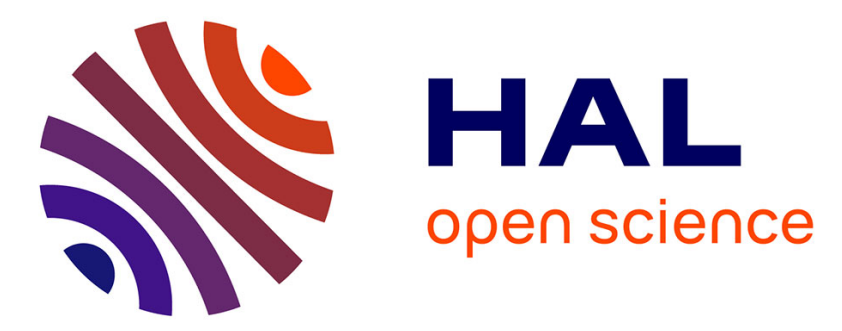

\title{
Stereoselective functionalization of pyrrolidinone moiety towards the synthesis of salinosporamide A
}

Julien Barbion, Geoffroy Sorin, Mohamed Selkti, Esther Kellenberger, Rachid Baati, Stefano Santoro, Fahmi Himo, Ange Pancrazi, Marie-Isabelle Lannou, Janick Ardisson

\section{To cite this version:}

Julien Barbion, Geoffroy Sorin, Mohamed Selkti, Esther Kellenberger, Rachid Baati, et al.. Stereoselective functionalization of pyrrolidinone moiety towards the synthesis of salinosporamide A. Tetrahedron, 2012, 68 (32), pp.6504-6512. 10.1016/j.tet.2012.05.103 . hal-02370605

\section{HAL Id: hal-02370605 https://hal.science/hal-02370605}

Submitted on 14 Oct 2021

HAL is a multi-disciplinary open access archive for the deposit and dissemination of scientific research documents, whether they are published or not. The documents may come from teaching and research institutions in France or abroad, or from public or private research centers.
L'archive ouverte pluridisciplinaire HAL, est destinée au dépôt et à la diffusion de documents scientifiques de niveau recherche, publiés ou non, émanant des établissements d'enseignement et de recherche français ou étrangers, des laboratoires publics ou privés. 


\title{
Stereoselective functionalization of pyrrolidinone moiety towards the synthesis of salinosporamide A
}

\author{
Julien Barbion ${ }^{\mathrm{a}}$, Geoffroy Sorin ${ }^{\mathrm{a}}$, Mohamed Selkti ${ }^{\mathrm{b}}$, Esther Kellenberger ${ }^{\mathrm{c}}$, Rachid Baati ${ }^{\mathrm{d}}$, \\ Stefano Santoro ${ }^{\mathrm{e}}$, Fahmi Himo ${ }^{\mathrm{e}}$, Ange Pancrazi ${ }^{\mathrm{a}}$, Marie-Isabelle Lannou ${ }^{\mathrm{a}, *}$, Janick Ardisson ${ }^{\mathrm{a}, *}$ \\ ${ }^{a}$ Faculté de Pharmacie, CNRS UMR 8638, Université Paris Descartes, 4 avenue de l'Observatoire, 75270 Paris Cedex, France \\ ${ }^{\mathrm{b}}$ Faculté de Pharmacie, CNRS UMR 8015, Université Paris Descartes, 4 avenue de l'Observatoire, 75270 Paris Cedex, France \\ ${ }^{\mathrm{c}}$ Faculté de Pharmacie, CNRS UMR 7200, Université de Strasbourg, 74 route du Rhin, 67400 Illkirch, France \\ ${ }^{\mathrm{d}}$ Faculté de Pharmacie, Université de Strasbourg, CNRS-UMR 7199, Laboratoire des Systèmes Chimiques Fonctionnels, 74 route du Rhin, 67400 Illkirch, BP 60024, France \\ e Department of Organic Chemistry, Arrhenius Laboratory, Stockholm University, S-106 91 Stockholm, Sweden
}

Keywords:

Salinosporamide

Hoppe allylation

Pyrrolidinone

Methylation reaction

Corey-Chaykovsky reaction

\begin{abstract}
A B S T R A C T
An important feature of the synthesis of salinosporamide A, a potent proteasome inhibitor, is the establishment of the quaternary stereocenter at C3. A new route has been developed based on the methylation of a functionalized pyrrolidinone. Direct methylation reaction led to the unwanted diastereomer; however, by means of a Corey-Chaykovsky reaction followed by $\mathrm{LiAlH}_{4}$ epoxide opening, the desired alcohol was obtained. The pyrrolidinone was elaborated through a key allylation reaction between a tertiary allyltitanium reagent and an aldehyde bearing a spiroketal moiety in $\alpha$-position.
\end{abstract}

\section{Introduction}

Recently, sea-water requiring microorganisms have begun to emerge as a new and sustainable source for novel chemical entities. For example, one particular rich source is the actinomycete bacteria of the genus Salinospora, which produces a very high potent and selective proteasome inhibitor, salinosporamide A $\mathbf{1}$. This marine product, discovered by Fenical, has been shown to possess in vitro cytotoxicity against many cancer cell lines with $\mathrm{IC}_{50}$ values less than $10 \mathrm{nM}$. Consequently, salinosporamide A $\mathbf{1}$ is currently in clinical trials for the treatment of cancer. ${ }^{1}$

Structurally, salinosporamide A 1 possesses a highly functionalized $\gamma$-lactam- $\beta$-lactone framework containing two contiguous tetrasubstituted carbon centres (Fig. 1 ). ${ }^{1}$

The global structural complexity of salinosporamide A $\mathbf{1}$ combined to its impressive biological profile makes it an attractive

\footnotetext{
* Corresponding authors. Tel.: +33 (0) 1537397 54; fax: +33 (0) 143291403 (M.-I.L.); tel.: +33 (0) 1537397 54; fax: +33 (0) 1432914 (J.A.); e-mail addresses: marie-isabelle.lannou@parisdescartes.fr (M.-I. Lannou), janick.ardisson@parisdescartes.fr (J. Ardisson)
}

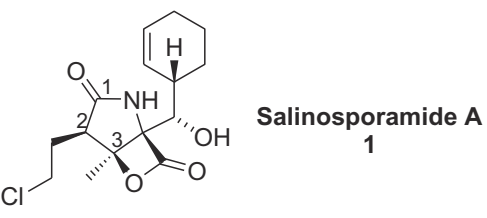

Fig. 1. Structure of salinosporamide A $\mathbf{1}$.

target for research studies in different fields, including total synthesis, structure-activity, biosynthetic engineering and crystallography with the $20 \mathrm{~S}$ proteasome.

One main feature of the salinosporamide A synthesis is the establishment of the quaternary centre at C3. Although different synthetic pathways have been proposed, ${ }^{2-5}$ the creation of the C3 centre was generally simultaneously produced with the pyrrolidine core by forming either $\mathrm{C} 2-\mathrm{C} 3^{3 \mathrm{a}, \mathrm{c}, \mathrm{f}, \mathrm{4b}, \mathrm{e}}$ or $\mathrm{C} 3-\mathrm{C} 4^{3 \mathrm{~d}, \mathrm{~g}-\mathrm{i}, \mathrm{k}-\mathrm{n}}$ bond, respectively (Schemes 1 and 2).

Key steps involved the Kulinkovitch, Baylis-Hillman or more frequently intramolecular aldol reaction.

Less often, the set-up of this centre was achieved directly on the functionalized pyrrolidine core through cyclization or dihydroxylation reaction (Scheme 3). ${ }^{\text {3b,e, } 4 \mathrm{a}, \mathrm{f}}$ 


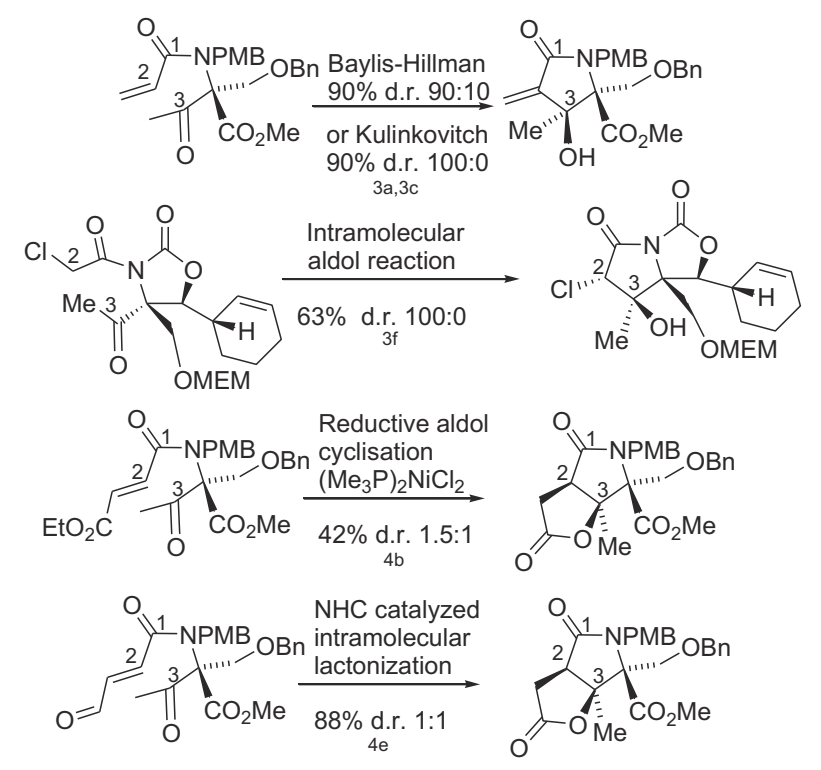

Scheme 1. Creation of the $\mathrm{C} 3$ centre by forming $\mathrm{C} 2-\mathrm{C} 3$ bond.<smiles>COC(=O)C(NC(=O)[C@@H](CCOCc1ccccc1)C1(C)OCCO1)C(=O)OC</smiles>
$(+/-)$<smiles>CC(=O)CN(C(=O)[C@@H](CCCl)C(C)=O)[C@@H](CBr)C(=O)O</smiles>

\section{biscyclisation} (aldol reaction, $\beta$-lactonisation) 4-PPY, MsCl

$52 \%$ d.r. $5: 1$ ee $90 \%$ $3 g-i, 3 n$

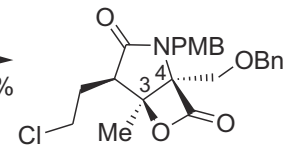

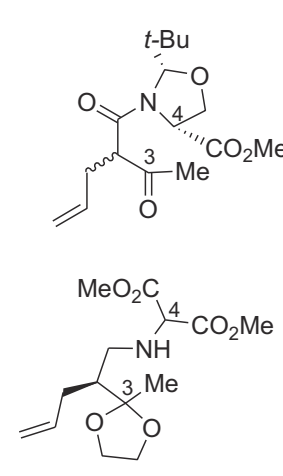<smiles>C=CC[C@H]1C(=O)N2C(C(C)(C)C)OC[C@]2(OC)[C@@]1(C)O</smiles>

intramolecular cyclization (aldol reaction)

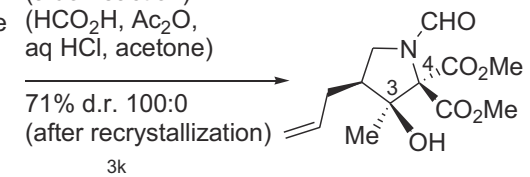

Scheme 2. Creation of the C3 centre by forming C3-C4 bond.

\section{Results and discussion}

For the synthesis of salinosporamide 1, our strategy involved the control of centre at C3 (salinosporamide carbon numbering) by stereoselective methylation of the pyrrolidinone 6 to provide alcohol 7 (Scheme 4). The preparation of this pyrrolidinone 6 depended on the elaboration of the homoallylic alcohol 5 through an allylation reaction.

Aldehyde allylation reaction by means of in situ generated chiral allyltitanium reagents, to yield anti homoallylic carbamates with excellent selectivity, has been initially developed by Hoppe and widely used in total synthesis by our group. ${ }^{6,7}$ In the design of a synthesis of salinosporamide A $\mathbf{1}$, we focused our attention on the

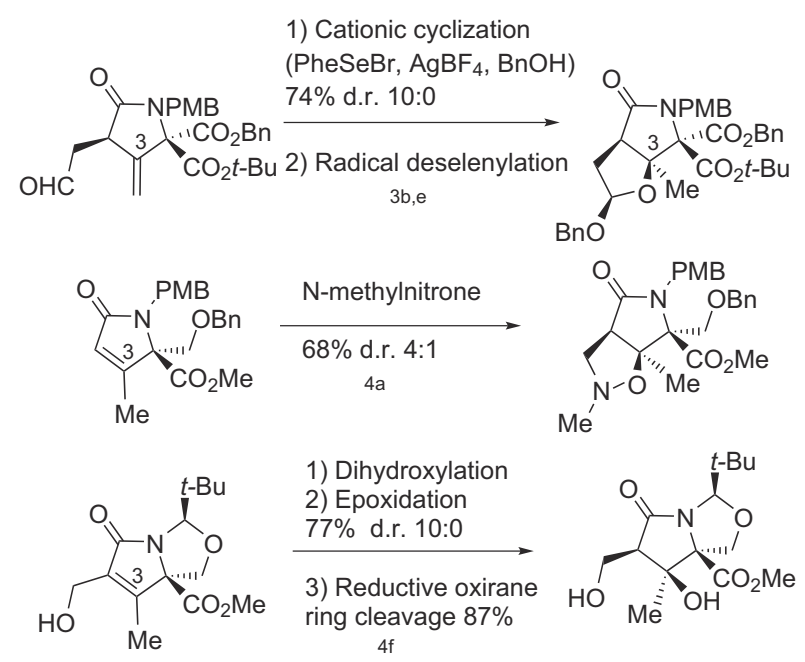

Scheme 3. Creation of the C3 centre directly on the functionalized pyrrolidine core.

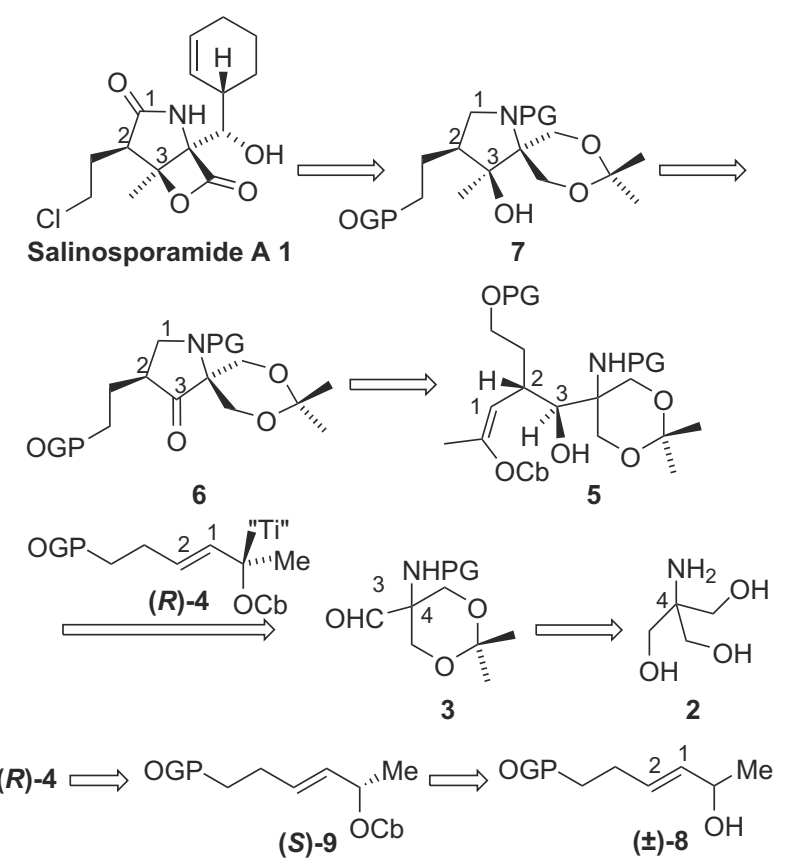

Scheme 4. Retrosynthetic strategy to salinosporamide A $\mathbf{1}$.

allylation of aldehyde $\mathbf{3}$ including a spiroketal moiety in $\alpha$-position by tertiary allyltitanium $(R)-\mathbf{4}$. Aldehyde 3 arose from 2-amino-2(hydroxymethyl)propane-1,3-diol (Tris) 2. Synthesis of allyltitanium $(R)-\mathbf{4}$ could be achieved through (+)-DIPT Sharpless epoxidation reaction of allylic alcohol $( \pm)-\mathbf{8}$ in a kinetic resolution strategy followed by carbamoylation reaction and treatment of the resulting allyl diisopropylcarbamate ( $S$ )-9 with $n$-BuLi/(-)-TMEDA and tetra-(isopropoxy)titanium, as described by us in previous publications. $^{7 \mathrm{~h}, \mathrm{i}}$

We examined this approach in a racemic version. Allylcarbamate $( \pm)$-11 was synthesized from homopropargylic alcohol in four steps: protection of the hydroxyl function, homologation, reduction of the triple bond and then carbamoylation of the resulting allylic alcohol ( \pm -10.

In the meantime, 2-amino-2-(hydroxymethyl)propane-1,3-diol (Tris) 2 was successively subjected to tert-butoxycarbonylation and acetalization to deliver alcohol $\mathbf{1 2}$ in $90 \%$ yield. Subsequent Swern oxidation afforded the corresponding aldehyde $\mathbf{1 3}$ (Scheme 5 ). ${ }^{8}$ 


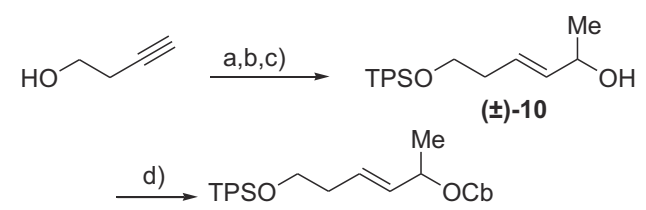

$( \pm)-11$

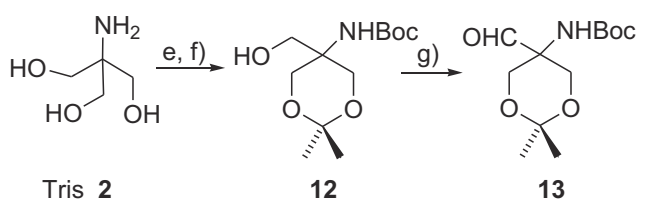

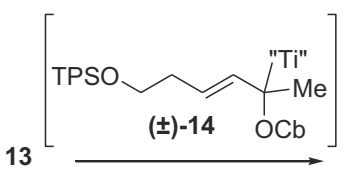

h)

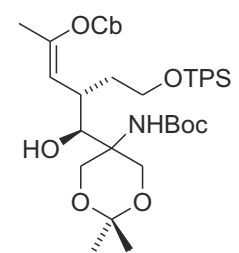

$( \pm)-15$
Scheme 5. Synthesis of the anti homoallylic alcohol ( \pm )-15. (a) Imidazole, TPSCl, THF rt, $24 \mathrm{~h}$; (b) $n$-BuLi in hexanes, THF, $-78^{\circ} \mathrm{C}, 1 \mathrm{~h}$ then $\mathrm{CH}_{3} \mathrm{CHO},-78^{\circ} \mathrm{C} \rightarrow \mathrm{rt}, 1 \mathrm{~h}$; (c) Red$\mathrm{Al}^{\circledR}$ in toluene, THF, $0{ }^{\circ} \mathrm{C}, 4 \mathrm{~h}, 94 \%$ over three steps; (d) $\mathrm{KH}, \mathrm{THF}, 0{ }^{\circ} \mathrm{C} \rightarrow \mathrm{rt}, 20 \mathrm{~min}$, then diisopropylcarbamoyl chloride, THF, rt, 0.5 h, 94\%; (e) $\mathrm{Boc}_{2} \mathrm{O}, t-\mathrm{BuOH} / \mathrm{MeOH}(1: 1), \mathrm{rt}$, $1 \mathrm{~h}$; (f) 2,2-dimethoxypropane, PTSA, $\mathrm{CH}_{2} \mathrm{Cl}_{2}$, rt, 0.5 h, $90 \%$ over two steps; (g) oxalyl chloride, DMSO, $\mathrm{CH}_{2} \mathrm{Cl}_{2}$, rt, $0.5 \mathrm{~h}$, then 12, $\mathrm{CH}_{2} \mathrm{Cl}_{2}, \mathrm{rt}, 0.5 \mathrm{~h}, 97 \%$; h) ( \pm )-11, TMEDA, nBuLi in hexanes, $\mathrm{Et}_{2} \mathrm{O},-78{ }^{\circ} \mathrm{C}, 1 \mathrm{~h}, \mathrm{Ti}(\mathrm{Oi}-\mathrm{Pr})_{4}$, then 13, THF, $-78{ }^{\circ} \mathrm{C}, 2 \mathrm{~h}, 76 \%, \mathrm{dr}>95: 5$. Red-Al ${ }^{\circledR}=$ Sodium bis(2-methoxyethoxy)aluminium hydride, TMEDA $=N, N, N^{\prime}, N^{\prime}$-Tetramethyl-ethane-1,2-diamine.

Hoppe allylation of the sterically hindered aldehyde $\mathbf{1 3}$ by tertiary allyltitanium $( \pm)-\mathbf{1 4}$ proceeded in high yield and total control of diastereoselectivity to provide anti homoallylic alcohol $( \pm)-\mathbf{1 5}$, having the framework of salinosporamide A. ${ }^{9}$ Allyltitanium $( \pm)-\mathbf{1 4}$ was readily prepared in situ from secondary allyl diisopropylcarbamate $( \pm)-\mathbf{1 1}$, through $n$-BuLi/TMEDA deprotonation and tetra-(isopropoxy)titanium transmetallation. ${ }^{7 \mathrm{~h}, \mathrm{i}}$

Exposure of vinylcarbamate $( \pm)-\mathbf{1 5}$ to ozone and subsequent treatment of the resulting hemiaminal with $\mathrm{NaBH}_{3} \mathrm{CN}$ produced 3hydroxypyrrolidine $( \pm)-\mathbf{1 6}$, which was further subjected to Dess-Martin oxidation to afford pyrrolidinone $( \pm)$-17 (Scheme 6 ).<smiles>CC(=O)OCC[C@H](C=C(C)O[OH2+])[C@@H](O)C1(N)COC(C)(C)OC1</smiles>

$( \pm)-15$

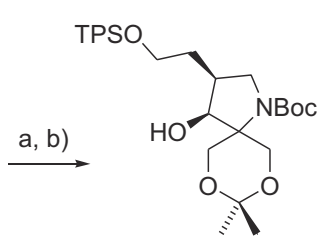

$( \pm)-16$

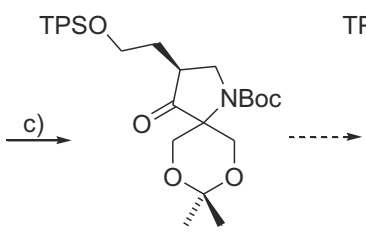

$( \pm)-17$

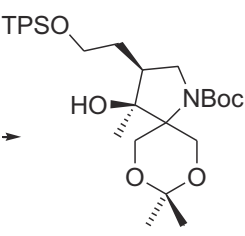

$( \pm)-18$
Scheme 6. Synthesis of the pyrrolidinone ( \pm )-17. (a) $\mathrm{O}_{3}, \mathrm{CH}_{2} \mathrm{Cl}_{2},-78{ }^{\circ} \mathrm{C}, 0.5 \mathrm{~h}, \mathrm{Me}_{2} \mathrm{~S}$, $-78{ }^{\circ} \mathrm{C} \rightarrow$ rt, overnight; (b) $\mathrm{NaBH}_{3} \mathrm{CN}, \mathrm{MeOH} / \mathrm{AcOH}$ (1:1), rt, 0.5 h, $50 \%$ over two steps; (c) Dess-Martin periodinane, $\mathrm{CH}_{2} \mathrm{Cl}_{2}, \mathrm{rt}, 1 \mathrm{~h}, 91 \%$.

At this stage, control of the C3 centre was envisioned through stereoselective methylation of pyrrolidinone $( \pm)-\mathbf{1 7}$ to access the tertiary alcohol $( \pm$ )-18 (Scheme 6). Very few publications have dealt with the controlled methylation of pyrrolidin-3-ones bearing an alkyl chain at C2 (salinosporamide carbon numbering). Therefore, based on literature reports, the diastereoselectivity of the alkylation of such functionalized pyrrolidinones could not be clearly predicted. $^{10}$

For this reason, a three-dimensional structure of the pyrrolidinone $( \pm)-\mathbf{1 7}$ was modelled using the Sybyl method. ${ }^{11}$ Although there is no strong steric hindrance of the $\mathrm{C} 3$ carbon by the vicinal spiroketal group and alkyl chain, pure geometric considerations would support a preferential addition of the methylating agent on the opposite side to the alkyl chain at $\mathrm{C} 2$, hypothetically leading to $( \pm)-\mathbf{1 8}$.

To validate this hypothesis, various methylating reagents were reacted with $( \pm)$-17. Among them, methylmagnesium bromide trimethylaluminium and dimethylzinc were inefficient in producing $( \pm)-\mathbf{1 8}$, resulting in the recovery of the starting material or its degradation. In contrast, the use of MeLi or MeLi/CeCl ${ }_{3},{ }^{12} \mathrm{de}-$ livered the unwanted tertiary alcohol derivative $( \pm)-\mathbf{1 9}$ as a single isomer in a satisfactory yield (along with starting material $( \pm)-17)$ (Scheme 7).

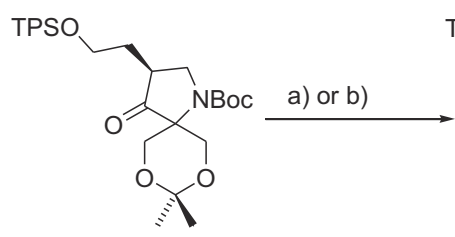

$( \pm)-17$

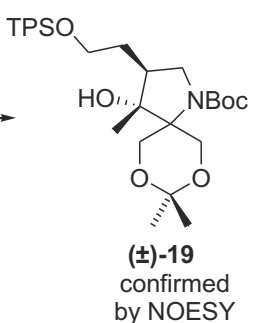

by NOESY
Scheme 7. Synthesis of the tertiary alcohol $( \pm)-\mathbf{1 9}$ through direct methylation. (a) MeLi, THF, $-78{ }^{\circ} \mathrm{C}, 4 \mathrm{~h}, 41 \%$, dr 100:0; (b) dried $\mathrm{CeCl}_{3}$ (from $\mathrm{CeCl}_{3} \cdot 7 \mathrm{H}_{2} \mathrm{O}$ ), MeLi, THF, $-78{ }^{\circ} \mathrm{C}, 2 \mathrm{~h}, 65 \%, \mathrm{dr}>95: 5$.

The configuration of the $\mathrm{C} 3$ centre was established by NOESY NMR experiments of pyrrolidine $( \pm)-\mathbf{1 9}$ and its corresponding $\gamma$ lactam $\left( \pm\right.$ )-20 (obtained from $\left( \pm\right.$ )-19 through $\mathrm{RuCl}_{3} \cdot \mathrm{H}_{2} \mathrm{O} / \mathrm{NaIO}_{4}$ oxidation) ${ }^{13}$ The structure was unambiguously confirmed by X-ray crystallography of the $\mathrm{O}-\mathrm{p}-\mathrm{NO}_{2} \mathrm{Bz}$ ester $( \pm)$-21 (Scheme 8).

Contrary to the predictions, the nucleophilic attack of the methyl group occurred from the same side as the $\mathrm{C} 2$ chain of ketone $( \pm)-\mathbf{1 7}$, resulting in the trans-disposition of the hydroxyl group and the chain.

To gain a better understanding of the reaction mechanism, density functional theory (DFT) calculations were performed on the methylation step. To model the reaction, a slightly modified system was used in order to reduce the number of rotamers that were needed to be investigated. Hence, the TPS group was substituted by a methyl, as well as the tert-butyl group of $\operatorname{Boc}\left(R^{1}=R=M e\right)$. Since the reaction was under kinetic control, the selectivity derives from the energy difference between transition states. Therefore, the two transition states leading to the two diastereomers have been optimized (see Fig. 2 for optimized structures and energies).

The calculations indeed show that the TS leading to the transproduct has a lower energy than the one leading to the cis-product (calculated difference is $1.1 \mathrm{kcal} / \mathrm{mol}$ ). This is an underestimation, due to the model used in the calculations, but it is still excellent considering the approximations made in the calculations. The energy difference probably arose from the different conformations of the five-membered ring in its transition states. While in the trans$\mathrm{TS}$, the ring assumes a preferred envelope-conformation, in the cisTS it resembles more a half-chair conformation. Furthermore, in the trans-TS, the bulky side chain is in an equatorial position, while it is forced to assume a 'less-equatorial' position in the cis-TS, due to the bending of the carbonyl towards the nucleophile.

These observations can explain the experimental observed findings. 
TPSO

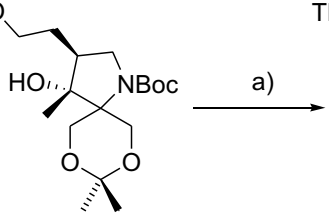

(士)-19

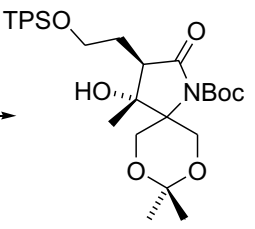

(士)-20

confirmed by NOESY

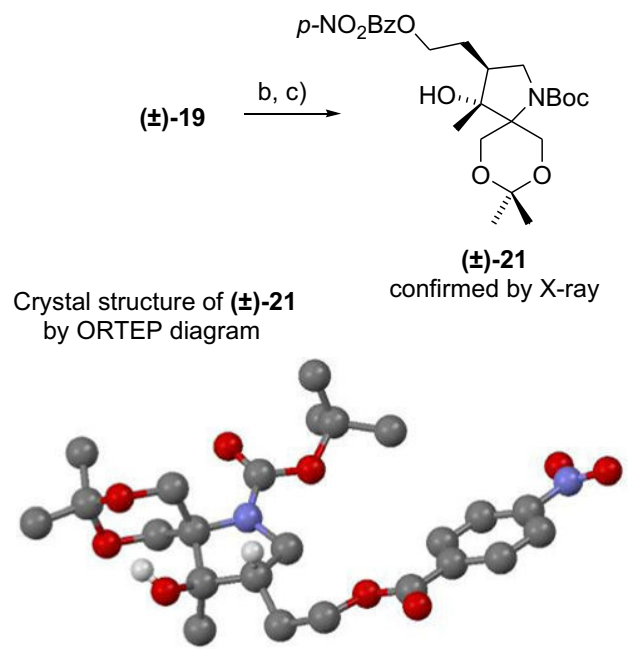

Scheme 8. Synthesis of lactam $( \pm)$-20 and ester $( \pm)$-21. (a) $\mathrm{RuCl}_{3} \cdot \mathrm{H}_{2} \mathrm{O}, \mathrm{NaIO} 4, \mathrm{NaHCO}_{3}$, AcOEt $/ \mathrm{H}_{2} \mathrm{O}$ (2:1), rt, $40 \mathrm{~h}$, non-optimized 52\%; (b) Bu $\mathrm{Bu}_{4} \mathrm{NF}$, THF, rt, 0.5 h; (c) $p-\mathrm{NO}_{2} \mathrm{BzCl}$, DMAP, $\mathrm{NEt}_{3}, \mathrm{CH}_{2} \mathrm{Cl}_{2}$, rt, $1 \mathrm{~h}, 61 \%$ over two steps. DMAP=4-Dimethylaminopyridine.
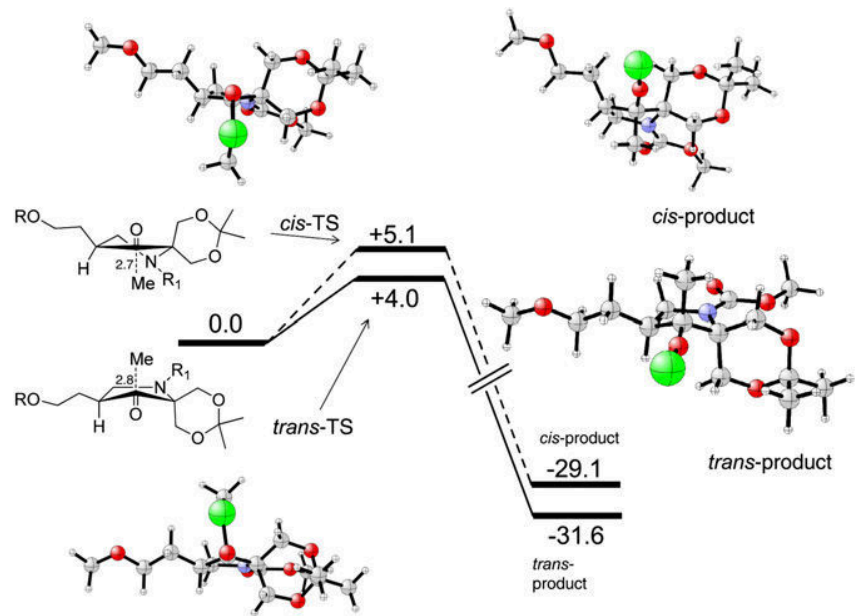

Fig. 2. DFT calculations performed on the methylation step: optimized structures and energies.

Experimentally, several attempts were achieved to overcome and reverse the unfavourable methylation selectivity.

The methylation reaction was examined with different starting materials using the same preceding experimental conditions ( $\mathrm{MeLi}$, THF/MeLi, $\mathrm{CeCl}_{3}, \mathrm{THF},-78{ }^{\circ} \mathrm{C}$ ). Among the methylation tested: (i) pyrrolidinones without spiroketal moiety at $\mathrm{C} 4,{ }^{14}$ (ii) linear ketones $^{15}$ and (iii) lactam, ${ }^{16}$ none of them gave satisfactory results. We also investigated the stereocontrolled facial addition of the methyl group in presence of optically active ligands and dimethylzinc: however, all attempts failed to give the expected product. ${ }^{17}$

Finally, an alternative sequential Corey-Chaykovsky reaction, dimethyloxosulfonium methylide as nucleophile in DMSO at $60{ }^{\circ} \mathrm{C}$, and subsequent $\mathrm{LiAlH}_{4}$ epoxide opening was envisioned starting from ketone $( \pm)-17{ }^{18}$ Under these conditions, the required alcohol

( \pm )-18 was obtained as a single isomer (Scheme 9). The relative stereochemistry of $( \pm)$-18 was determined unambiguously by 2DNOESY experiments and compared to whose obtained for $( \pm)$-19. It is important to note that starting from the same substrate $( \pm)-\mathbf{1 7}$, different reagents ( $\mathrm{MeLi} / \mathrm{CeCl}_{3}$ or sulfoxonium ylide as nucleophile) led to opposite selectivity. Unfortunately, to date, no valuable hypothesis can be proposed to explain this reversal of selectivity. Kinetic or thermodynamic control could be suggested.

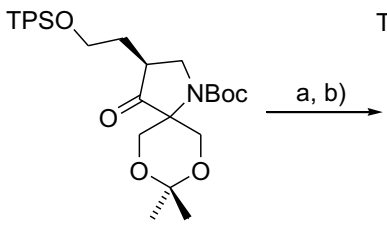

(士)-17

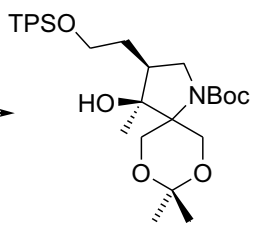

$( \pm)-18$

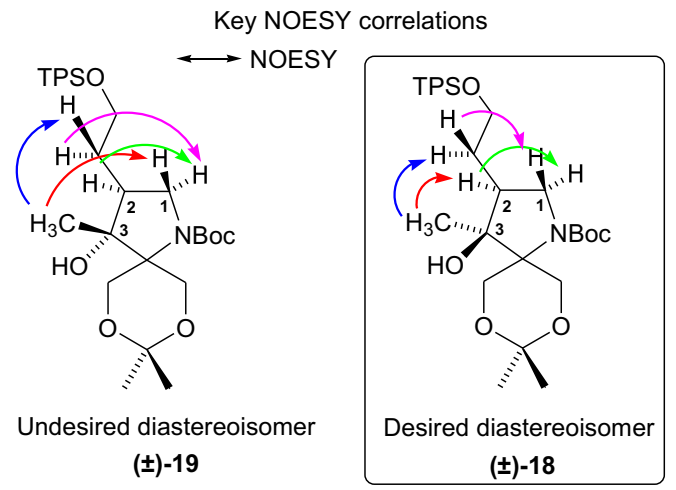

Scheme 9. Elaboration of the required alcohol ( \pm )-18. a) $\mathrm{Me}_{3} \mathrm{SOI}, \mathrm{NaH}, \mathrm{DMSO}, \mathrm{rt}, 0.5 \mathrm{~h}$, then $( \pm)-15,60{ }^{\circ} \mathrm{C}, 1.5 \mathrm{~h}$; b) $\mathrm{LiAlH}_{4}, \mathrm{Et}_{2} \mathrm{O}, 0^{\circ} \mathrm{C} \rightarrow \mathrm{rt}, 0.5 \mathrm{~h}$, non-optimized $52 \%$ over two steps, dr $>95: 5$.

Noteworthy, pyrrolidinol $( \pm)-\mathbf{1 8}$ is structurally very close to the advanced intermediate $( \pm)$-22 described by Pattenden during the course to total synthesis of salinosporamide $\mathbf{1}$ (Scheme 10). ${ }^{31, \mathrm{~m}}$<smiles>COC(=O)[C@]1(O)NC(=O)[C@H](CCOCc2ccccc2)[C@@]1(C)O</smiles>

$(+/-)-22$

Scheme 10. Pattenden advanced intermediate $( \pm)-\mathbf{2 2}$.

\section{Conclusion}

Towards the synthesis of the salinosporamide pyrrolidine core, two key-steps have been studied. At first, a novel high-yielding allylation reaction between a tertiary allyltitanium reagent and an aldehyde bearing a spiroketal moiety in $\alpha$-position was described. This reaction readily offered access to the entire core of salinosporamide A. The second step was the control of the diastereoselectivity of the quaternary stereocenter at C3. We expected that the methylation of the corresponding substituted pyrrolidinone $( \pm)$-17 would deliver the right diastereomer, assuming that methylating agents would add from the less hindered direction. Surprisingly, using $\mathrm{MeLi}$ or $\mathrm{MeLi} / \mathrm{CeCl}_{3}$ reagents under kinetic control, the undesired tertiary alcohol $( \pm)-\mathbf{1 9}$ was isolated as a single isomer. DFT calculations, performed on this methylation step, explained this result and improved our understanding of the transition states. Finally, an alternative sequential Corey-Chaykovsky reaction/ $\mathrm{LiAlH}_{4}$ epoxide opening produced the expected alcohol $( \pm)$-18. This result obviously established that the Corey-Chaykovsky reaction, with sulfoxonium ylide as nucleophile, occurred with an opposite stereoselectivity. 
Importantly, the potential and applicability of this approach for the synthesis of salinosporamide A $\mathbf{1}$ have been demonstrated with the synthesis of the pyrrolidinol $( \pm)-\mathbf{1 8}$.

\section{Experimental section}

\subsection{General}

All commercially available reagents and solvents (Fluka, Aldrich, Acros, Fisher) were used without further purification. For reactions requiring anhydrous conditions, dry solvents were bought (Fluka, Aldrich) or freshly distillated prior to use (THF and $\mathrm{Et}_{2} \mathrm{O}$ over sodium/benzophenone system, DCM and DMSO over calcium hydride and $\mathrm{MeOH}$ and $\mathrm{EtOH}$ over magnesium). Unless otherwise noted, experiments were carried out under argon. Reactions were monitored by TLC (Merck silica gel $60 \mathrm{~F}_{254}$ plates) with detection by use of UV light ( $254 \mathrm{~nm} \& 366 \mathrm{~nm}$ ) or a phosphomolybdic acid solution in EtOH (5\%) followed by heating at $100-110{ }^{\circ} \mathrm{C}$. Purifications were performed by flash chromatography on silica gel (Merck silica gel $60,40-63 \mu \mathrm{m}) .{ }^{1} \mathrm{H}$ NMR spectra were recorded with Bruker AVANCE 300 and AVANCE 400 spectrometers at, respectively 300 and $400 \mathrm{MHz}$. Chemical shifts are given in parts per million relative to the residual ${ }^{1} \mathrm{H}$ solvent signal $\left(\mathrm{CDCl}_{3}: \delta=7.26 \mathrm{ppm}\right)$ as the internal reference. ${ }^{1} \mathrm{H}$ NMR assignments were confirmed by 2D COSY spectra. The multiplicities given reflect apparent signal patterns. ${ }^{13} \mathrm{C}$ NMR spectra were recorded with the same instruments as above at $100 \mathrm{MHz}$. Chemical shifts are given in ppm relative to the residual ${ }^{13} \mathrm{C}$ solvent signal $\left(\mathrm{CDCl}_{3}: \delta=77.0 \mathrm{ppm}\right) .{ }^{13} \mathrm{C}$ NMR assignments were confirmed by 2D HSQC spectra. Coupling constants $(J)$ are given in hertz for all NMR spectroscopic data. Melting points were measured with a Büchi 510 apparatus and are uncorrected. IR spectra were recorded with a Perkin Elmer Spectrum 65 FT-IR spectrometer. Mass spectra were recorded with the following instruments: ESI-MS: Waters ZQ 2000 spectrometer and ESI-TOF-HRMS: Waters LCT Premier spectrometer. CCDC-857729 [( \pm$)$-19] contain the supplementary crystallographic data. The data can be obtained free of charge from the Cambridge Crystallographic Data Centre TH through http://www.ccdc.cam.ac.uk/.

Computational details. All calculations were performed using the B3LYP functional ${ }^{19}$ as implemented in the Gaussian 03 software package. ${ }^{20}$ Geometries were optimized with the $6-31 \mathrm{G}(\mathrm{d}, \mathrm{p})$ basis set for all atoms, and characterized with frequency calculations. Final energies were obtained with the larger $6-311+G(2 d, 2 p)$ basis set on all atoms and corrected for zero-point effects obtained from the frequency calculations. The effect of solvation in THF was calculated using the conductor-like polarizable continuum model $(\mathrm{CPCM})^{21}$ with UAKS radii.

\section{2. (E)-6-[(tert-Butyldiphenylsilyl)oxy]hex-3-en-2-ol ( \pm )-10}

Imidazole (3.47 g, $51.0 \mathrm{mmol}$ ), DMAP (186 mg, $1.5 \mathrm{mmol}$ ) and TPSCl (12 mL, $45.0 \mathrm{mmol}$ ) were successively added to a solution of 3-butyn-1-ol (2.21 g, $30.0 \mathrm{mmol})$ in THF (60 mL). The reaction mixture was stirred at room temperature for $24 \mathrm{~h}$ and then $\mathrm{H}_{2} \mathrm{O}$ $(90 \mathrm{~mL})$ was added. The mixture was extracted with EtOAc. The organic layers were washed with brine, dried $\left(\mathrm{MgSO}_{4}\right)$, filtered and the solvent removed under reduced pressure. The residue was purified by chromatography on silica gel (cyclohexane/Et ${ }_{2} \mathrm{O} 99: 1$ to $98: 2$ ) to give $11.07 \mathrm{~g}$ of 4 -[(tert-butyldiphenylsilyl)oxy]but-1-yne as a colourless oil.

${ }^{1} \mathrm{H}$ NMR (400 MHz, $\left.\mathrm{CDCl}_{3}\right): \delta=7.60(\mathrm{~m}, 4 \mathrm{H}), 7.33(\mathrm{~m}, 6 \mathrm{H}), 3.71(\mathrm{t}$, $J=0.9 \mathrm{~Hz}, 2 \mathrm{H}), 2.38(\mathrm{t}, J=0.9 \mathrm{~Hz}, 2 \mathrm{H}), 1.88(\mathrm{~s}, 1 \mathrm{H}), 0.98(\mathrm{~s}, 9 \mathrm{H}) \mathrm{ppm}$. ${ }^{13} \mathrm{C}$ NMR $\left(100 \mathrm{MHz}, \mathrm{CDCl}_{3}\right): \delta=135.6,133.5,129.7,127.7,81.4,69.3$, 62.2, 26.7, 22.5, $19.2 \mathrm{ppm}$

A solution of $n$-BuLi (1.6 M in hexanes, $21 \mathrm{~mL}, 33.7 \mathrm{mmol}$ ) was added to a solution of the previous product $(30.0 \mathrm{mmol})$ in THF
(60 $\mathrm{mL}$ ) at $-78{ }^{\circ} \mathrm{C}$. The reaction mixture was stirred at $-78{ }^{\circ} \mathrm{C}$ for $1 \mathrm{~h}$ and then freshly distillated acetaldehyde $(4.4 \mathrm{~mL}, 76.5 \mathrm{mmol})$ was added quickly. The reaction mixture was warmed up to room temperature and stirred for $1 \mathrm{~h}$ before $\mathrm{HCl}(1.0 \mathrm{M}, 20 \mathrm{~mL})$ was added. The mixture was extracted with $\mathrm{Et}_{2} \mathrm{O}$. The organic layers were washed subsequently with $\mathrm{H}_{2} \mathrm{O}$ and brine, dried $\left(\mathrm{MgSO}_{4}\right)$, filtered and the solvent removed under reduced pressure. The residue was purified by chromatography on silica gel (cyclohexane) EtOAc 1:1) to give $13.47 \mathrm{~g}$ of 6-[(tert-butyldiphenylsilyl)oxy]hex-3yn-2-ol as a yellow oil.

${ }^{1} \mathrm{H}$ NMR (400 MHz, $\left.\mathrm{CDCl}_{3}\right): \delta=7.60(\mathrm{~m}, 4 \mathrm{H}), 7.33(\mathrm{~m}, 6 \mathrm{H}), 4.40$ $(\mathrm{m}, 1 \mathrm{H}), 3.69(\mathrm{t}, J=6.9 \mathrm{~Hz}, 2 \mathrm{H}), 2.40(\mathrm{td}, J=6.9 / 1.8 \mathrm{~Hz}, 2 \mathrm{H}), 1.64(\mathrm{~s}$, $1 \mathrm{H}), 1.32(\mathrm{~d}, J=6.4 \mathrm{~Hz}, 3 \mathrm{H}), 0.98(\mathrm{~s}, 9 \mathrm{H}) \mathrm{ppm} .{ }^{13} \mathrm{C} \mathrm{NMR}(100 \mathrm{MHz}$, $\left.\mathrm{CDCl}_{3}\right): \delta=135.5,133.5,129.7,127.6,83.1,81.6,62.3,58.8,26.7,24.5$, 22.8, $19.2 \mathrm{ppm}$.

A solution of Red-Al ${ }^{\circledR}(3.5 \mathrm{M}$ in toluene, $14 \mathrm{~mL}, 49.0 \mathrm{mmol})$ was added to a solution of the previous product $(30.0 \mathrm{mmol})$ in THF $(60 \mathrm{~mL})$ at $0{ }^{\circ} \mathrm{C}$. The reaction mixture was stirred at this temperature for $4 \mathrm{~h}$ and then quenched by a slow addition of $\mathrm{HCl}(1.0 \mathrm{M}$, $50 \mathrm{~mL}$ ). The reaction mixture was warmed up to room temperature and then extracted with $\mathrm{Et}_{2} \mathrm{O}$. The organic layers were washed with $\mathrm{NaHCO}_{3}$ and brine, dried $\left(\mathrm{MgSO}_{4}\right)$, filtered and the solvent removed under reduced pressure. The residue was purified by chromatography on silica gel (cyclohexane/Et ${ }_{2} \mathrm{O} 1: 1$ ) to give $10.24 \mathrm{~g}$ (94\% yield over three steps) of required product $( \pm)-\mathbf{1 0}$ as a colourless oil.

${ }^{1} \mathrm{H} \mathrm{NMR}\left(400 \mathrm{MHz}, \mathrm{CDCl}_{3}\right): \delta=7.59(\mathrm{~m}, 4 \mathrm{H}), 7.33(\mathrm{~m}, 6 \mathrm{H}), 5.51(\mathrm{~m}$, $2 \mathrm{H}), 4.16(\mathrm{~m}, 1 \mathrm{H}), 3.63(\mathrm{t}, J=6.9 \mathrm{~Hz}, 2 \mathrm{H}), 2.20(\mathrm{td}, J=6.9 / 6.4 \mathrm{~Hz}, 2 \mathrm{H})$, $1.30(\mathrm{~s}, 1 \mathrm{H}), 1.16(\mathrm{~d}, J=6.4 \mathrm{~Hz}, 3 \mathrm{H}), 0.98(\mathrm{~s}, 9 \mathrm{H}) \mathrm{ppm} .{ }^{13} \mathrm{C} \mathrm{NMR}$ $\left(100 \mathrm{MHz}, \mathrm{CDCl}_{3}\right): \delta=136.1,135.6,133.9,129.6,127.6,127.4,68.9$, 63.4, 35.5, 26.8, 23.2, $19.2 \mathrm{ppm}$.

\section{3. (E)-6-[(tert-Butyldiphenylsilyl)oxy]hex-3-en-2-yl diisopropylcarbamate $( \pm)-11$}

A solution of the precedent alkene $( \pm)-\mathbf{1 0}(9.52 \mathrm{~g}, 26.8 \mathrm{mmol})$ in THF ( $45 \mathrm{~mL})$ was added to a solution of $\mathrm{KH}(30 \%$ in mineral oil, $5.11 \mathrm{~g}, 37.6 \mathrm{mmol}$ ), previously washed with cyclohexane, in THF $(40 \mathrm{~mL})$ at $0{ }^{\circ} \mathrm{C}$. The reaction mixture was stirred at $0{ }^{\circ} \mathrm{C}$ for $5 \mathrm{~min}$ and for 20 additional minutes at room temperature. Then, a solution of diisopropylcarbamoyl chloride $(5.0 \mathrm{~g}, 29.5 \mathrm{mmol})$ in THF $(20 \mathrm{~mL})$ was added and the mixture was stirred for $30 \mathrm{~min}$ at room temperature. The reaction mixture was neutralized by addition of $\mathrm{HCl}(1.0 \mathrm{M}, 35 \mathrm{~mL})$ at $0{ }^{\circ} \mathrm{C}$, warmed up to room temperature and then extracted with $\mathrm{Et}_{2} \mathrm{O}$. The organic layers were washed with brine, dried $\left(\mathrm{Na}_{2} \mathrm{SO}_{4}\right)$, filtered and the solvent removed under reduced pressure. The residue was purified by chromatography on silica gel (cyclohexane/ $\mathrm{Et}_{2} \mathrm{O}$ 9:1) to give $12.14 \mathrm{~g}$ (94\% yield) of the required product $( \pm)-\mathbf{1 1}$ as a colourless oil.

${ }^{1} \mathrm{H}$ NMR (400 MHz, $\left.\mathrm{CDCl}_{3}\right): \delta=7.61(\mathrm{~m}, 4 \mathrm{H}), 7.33(\mathrm{~m}, 6 \mathrm{H}), 5.62$ (td, $J=15.6 / 6.9 \mathrm{~Hz}, 1 \mathrm{H}$ ), 5.49 (dd, $J=15.6 / 6.0 \mathrm{~Hz}, 1 \mathrm{H}$ ), 5.20 (td, $J=6.4 /$ $6.0 \mathrm{~Hz}, 1 \mathrm{H}), 4.03$ (s large, 1H), $3.61(\mathrm{t}, J=6.9 \mathrm{~Hz}, 2 \mathrm{H}), 3.59(\mathrm{~s}, 1 \mathrm{H}), 2.21$ $(\mathrm{td}, J=6.9 / 6.9 \mathrm{~Hz}, 2 \mathrm{H}), 1.22(\mathrm{~d}, J=6.4 \mathrm{~Hz}, 3 \mathrm{H}), 1.11(\mathrm{~d}, J=6.9 \mathrm{~Hz}, 12 \mathrm{H})$, $0.96(\mathrm{~s}, 9 \mathrm{H})$ ppm. ${ }^{13} \mathrm{C}$ NMR $\left(100 \mathrm{MHz}, \mathrm{CDCl}_{3}\right): \delta=155.1,135.5,133.9$, 132.6, 129.5, 128.2, 127.6, 71.0, 63.4, 46.6, 45.6, 35.6, 26.8, 26.7, 20.7, $19.2 \mathrm{ppm}$. IR (thin film): $\nu=2931,1687,1473,1428,1368,1286,1215$, 1107, 1045, 967, 925, 822, 770, $737 \mathrm{~cm}^{-1}$. MS (40 eV, ES): $m / z(\%)$ : $520(5)[\mathrm{M}+\mathrm{K}]^{+}, 504(100)[\mathrm{M}+\mathrm{Na}]^{+}, 102(10)$. ESI-HRMS: calcd for $\mathrm{C}_{29} \mathrm{H}_{43} \mathrm{NO}_{3} \mathrm{Si}[\mathrm{M}+\mathrm{Na}]^{+}$504.2910; found 504.2901.

\section{4. tert-Butyl-5-(hydroxymethyl)-2,2-dimethyl-1,3-dioxan-5- ylcarbamate 12}

A solution of $\mathrm{Boc}_{2} \mathrm{O}(7.0 \mathrm{~mL}, 32.5 \mathrm{mmol})$ in $t-\mathrm{BuOH}(12.5 \mathrm{~mL})$ was added to a solution of trishydroxymethylaminomethane (Tris) 2 $(3.0 \mathrm{~g}, 25.0 \mathrm{mmol})$ in a mixture $t-\mathrm{BuOH} / \mathrm{MeOH}(1: 1)(50 \mathrm{~mL})$. The reaction mixture was stirred at room temperature for $24 \mathrm{~h}$. The 
solvent was removed under reduced pressure and the crude tertbutyl-1,3-dihydroxy-2-(hydroxymethyl)propan-2-ylcarbamate was isolated as a white powder.

${ }^{1} \mathrm{H} \mathrm{NMR}\left(400 \mathrm{MHz}, \mathrm{CDCl}_{3}\right): \delta=5.44(\mathrm{~s}, 1 \mathrm{H}), 3.61(\mathrm{~d}, J=5.9 \mathrm{~Hz}, 6 \mathrm{H})$, $3.30(\mathrm{t}, J=5.9 \mathrm{~Hz}, 3 \mathrm{H}), 1.20(\mathrm{~s}, 9 \mathrm{H}) \mathrm{ppm} .{ }^{13} \mathrm{C} \mathrm{NMR}\left(100 \mathrm{MHz}, \mathrm{CDCl}_{3}\right)$ : $\delta=157.0,80.5,63.9,59.6,28.3 \mathrm{ppm}$.

2,2-Dimethoxypropane (9.4 mL, $75.0 \mathrm{mmol}$ ) and PTSA (240 mg, $1.25 \mathrm{mmol}$ ) were added to a solution of the previous crude product (25.0 mmol in theory) in $\mathrm{CH}_{2} \mathrm{Cl}_{2}(125 \mathrm{~mL}$ ). The reaction mixture was stirred at room temperature for $30 \mathrm{~min}$ and then neutralized with $\mathrm{Et}_{3} \mathrm{~N}(210 \mu \mathrm{L}, 1.5 \mathrm{mmol})$. The solvent was removed under reduced pressure and the residue was purified by chromatography on silica gel (cyclohexane/EtOAc 1:1) to give $5.89 \mathrm{~g}$ (90\% yield over two steps) of the required product $\mathbf{1 2}$ as a white powder.

${ }^{1} \mathrm{H}$ NMR $\left(400 \mathrm{MHz}, \mathrm{CDCl}_{3}\right): \delta=5.27$ (broad s, $\left.1 \mathrm{H}\right), 4.22(\mathrm{~s}, 1 \mathrm{H})$, $3.78(\mathrm{~m}, 2 \mathrm{H}), 3.74(\mathrm{~m}, 2 \mathrm{H}), 3.66(\mathrm{~d}, J=6.9 \mathrm{~Hz}, 2 \mathrm{H}), 1.39(\mathrm{~s}, 9 \mathrm{H}), 1.37$ (s, $6 \mathrm{H}) \mathrm{ppm} .{ }^{13} \mathrm{C}$ NMR $\left(100 \mathrm{MHz}, \mathrm{CDCl}_{3}\right): \delta=156.4,98.7,80.5,64.7,64.4$, 53.3, $28.3 \mathrm{ppm}$.

\section{5. tert-Butyl-5-formyl-2,2-dimethyl-1,3-dioxan-5- ylcarbamate 13}

DMSO (4.8 $\mathrm{mL}, 67.6 \mathrm{mmol}$ ) was added to a solution of oxalyl chloride $(4.0 \mathrm{~mL}, 45.1 \mathrm{mmol})$ in $\mathrm{CH}_{2} \mathrm{Cl}_{2}(110 \mathrm{~mL})$ at $-78{ }^{\circ} \mathrm{C}$. The reaction mixture was stirred at room temperature for $30 \mathrm{~min}$. Then, a solution of alcohol $12(5.89 \mathrm{~g}, 22.5 \mathrm{mmol})$ in $\mathrm{CH}_{2} \mathrm{Cl}_{2}(32 \mathrm{~mL})$ is added to the mixture. After $30 \mathrm{~min}, \mathrm{Et}_{3} \mathrm{~N}(19 \mathrm{~mL}, 135.2 \mathrm{mmol}$ ) was added and the mixture warmed to room temperature and stirred for additional $30 \mathrm{~min}$. $\mathrm{HCl}(1.0 \mathrm{M}, 12.5 \mathrm{~mL})$ was added and the solution was extracted with $\mathrm{CH}_{2} \mathrm{Cl}_{2}$. The organic layers were combined, washed with $\mathrm{NaHCO}_{3}$ and then with brine, dried $\left(\mathrm{MgSO}_{4}\right)$. After filtration, the solvent was removed under reduced pressure. The residue was purified by chromatography on silica gel (cyclohexane/EtOAc 8:2) to give $5.63 \mathrm{~g}$ (97\% yield) of the required product 13 as a yellow powder.

Mp $62{ }^{\circ} \mathrm{C} .{ }^{1} \mathrm{H}$ NMR $\left(400 \mathrm{MHz}, \mathrm{CDCl}_{3}\right): \delta=9.55(\mathrm{~s}, 1 \mathrm{H}), 5.62(\mathrm{~s}, 1 \mathrm{H})$, $4.00(\mathrm{~m}, 2 \mathrm{H}), 3.85(\mathrm{~m}, 2 \mathrm{H}), 1.40(\mathrm{~s}, 15 \mathrm{H}) \mathrm{ppm} .{ }^{13} \mathrm{C}$ NMR $(100 \mathrm{MHz}$, $\left.\mathrm{CDCl}_{3}\right): \delta=199.3,155.4,98.6,80.8,62.5,59.7,28.1,27.1,19.5$ ppm. IR (thin film): $\nu=3343,2980,2936,1696,1502,1454,1367,1248,1202$, $1159,1078,1050,938,829,782,732,707 \mathrm{~cm}^{-1}$. MS (30 eV, ES): $m / z$ (\%): 298 (11) $[\mathrm{M}+\mathrm{K}]^{+}, 282(100)[\mathrm{M}+\mathrm{Na}]^{+}, 226$ (12), 153 (15), 146 (6), 102 (8). ESI-HRMS: calcd for $\mathrm{C}_{12} \mathrm{H}_{21} \mathrm{NO}_{5}[\mathrm{M}+\mathrm{Na}]^{+}$282.1317; found 282.1326 .

\subsection{5-(1S $\left., 2 S^{*}, 3 Z\right)-5-\{N$-tert-Butyloxycarbonyl-2-[(tert- butyldiphenylsilyl)oxy]ethyl-4-diisopropylcarbamoyloxy- pent-3-en-1-ol\}-2,2-dimethyl-1,3-dioxane ( \pm )-15}

TMEDA (7.6 mL, $50.4 \mathrm{mmol}$ ) and $n$-BuLi (1.6 $\mathrm{M}$ in hexanes, $31.5 \mathrm{~mL}, 50.4 \mathrm{mmol}$ ) were successively added to a solution of carbamate $9(12.14 \mathrm{~g}, 25.2 \mathrm{mmol})$ in $\mathrm{Et}_{2} \mathrm{O}(20 \mathrm{~mL})$ at $-78{ }^{\circ} \mathrm{C}$. After $1 \mathrm{~h}$ stirring, were added freshly distillated $\mathrm{Ti}(\mathrm{O} i-\mathrm{Pr})_{4}(22.6 \mathrm{~mL}$, $75.6 \mathrm{mmol}$ ) (orange colouration through the transmetallation reaction) and then, a solution of aldehyde $13(5.97 \mathrm{~g}, 22.9 \mathrm{mmol})$ in THF $(85 \mathrm{~mL})$. The mixture was stirred for $2 \mathrm{~h}$ at $-78^{\circ} \mathrm{C}$, neutralized by addition of $\mathrm{HCl}(1.0 \mathrm{M}, 230 \mathrm{~mL})$ and warmed up to room temperature. The mixture was filtrated through a pad of Celite ${ }^{\circledR}$ and extracted with $\mathrm{Et}_{2} \mathrm{O}$. The organic layers were washed with $\mathrm{NaHCO}_{3}$ and brine, dried $\left(\mathrm{MgSO}_{4}\right)$, filtered and the solvent removed under reduced pressure. The residue was purified by chromatography on silica gel (cyclohexane/Et ${ }_{2} \mathrm{O} 8: 2$ to $6: 4$ ) to give $9.70 \mathrm{~g}$ (76\% yield) of the required product $( \pm)-\mathbf{1 5}$ as a viscous colourless oil.

${ }^{1} \mathrm{H}$ NMR (400 MHz, $\mathrm{CDCl}_{3}$ ): $\delta=7.68(\mathrm{~m}, 4 \mathrm{H}), 7.40(\mathrm{~m}, 6 \mathrm{H}), 6.12$ (broad s, 1H), $5.14(\mathrm{~d}, J=10.5 \mathrm{~Hz}, 1 \mathrm{H}), 5.08(\mathrm{~d}, J=11.9 \mathrm{~Hz}, 1 \mathrm{H}), 4.36(\mathrm{~d}$, $J=11.9 \mathrm{~Hz}, 1 \mathrm{H}), 4.05(\mathrm{~m}, 3 \mathrm{H}), 3.71(\mathrm{~m}, 4 \mathrm{H}), 2.54(\mathrm{~m}, 1 \mathrm{H}), 1.86(\mathrm{~s}, 3 \mathrm{H})$, $1.83(\mathrm{~m}, 2 \mathrm{H}), 1.46(\mathrm{~s}, 9 \mathrm{H}), 1.41(\mathrm{~s}, 3 \mathrm{H}), 1.38(\mathrm{~s}, 3 \mathrm{H}), 1.15(\mathrm{~m}, 12 \mathrm{H}), 1.05$ (s, 9H) ppm. ${ }^{13} \mathrm{C} \mathrm{NMR}\left(100 \mathrm{MHz}, \mathrm{CDCl}_{3}\right): \delta=158.1,153.8,144.5,135.6$, 133.9, 129.5, 127.6, 116.5, 98.7, 79.8, 75.6, 64.3, 63.7, 62.4, 56.4, 46.6, 45.6, 36.5, 33.8, 28.4, 26.9, 24.2, 23.0, 21.8, 21.6, 20.6, 20.4, 20.2, $19.2 \mathrm{ppm}$. IR (thin film): $\nu=3319,2967,2932,1674,1623,1473,1428$, 1369, 1294, 1256, 1228, 1203, 1154, 1110, 1087, 1044, 908, 824, 784, 730, $701 \mathrm{~cm}^{-1}$. MS (30 eV, ES): $m / z(\%): 780(9)[\mathrm{M}+\mathrm{K}]^{+}, 764(50)$ $[\mathrm{M}+\mathrm{Na}]^{+}, 520(41), 504$ (53), 323 (17), $314(30), 282$ (100), 226 (16). ESI-HRMS: calcd for $\mathrm{C}_{41} \mathrm{H}_{64} \mathrm{~N}_{2} \mathrm{O}_{8} \mathrm{Si}[\mathrm{M}+\mathrm{Na}]^{+}$763.4330; found 763.4348

\section{7. $5-\left(3 R^{*}, 4 S^{*}\right)-5-\{N$-tert-Butyloxycarbonyl-3-[(tert- butyldiphenylsilyl)oxy]ethyl-4-hydroxy-pyrrolidine\}-2,2- dimethyl-1,3-dioxane $( \pm)-16$}

Through a solution of vinylcarbamate $( \pm)-\mathbf{1 5}(2.41 \mathrm{~g}, 3.25 \mathrm{mmol})$ in $\mathrm{CH}_{2} \mathrm{Cl}_{2}(16 \mathrm{~mL})$ at $-78{ }^{\circ} \mathrm{C}$ was bubbled an ozone flow. After $30 \mathrm{~min}$ reaction (TLC control), the ozone was replaced by argon for $10 \mathrm{~min}$. Then, $\mathrm{Me}_{2} \mathrm{~S}(9.7 \mathrm{~mL}, 129.9 \mathrm{mmol}$ ) was added and the mixture was warmed up to room temperature and stirred overnight. The mixture was extracted with $\mathrm{CH}_{2} \mathrm{Cl}_{2}$ and the organic layers were washed with $\mathrm{H}_{2} \mathrm{O}$, dried $\left(\mathrm{Na}_{2} \mathrm{SO}_{4}\right)$, filtered and the solvent removed under reduced pressure. To a solution of the previous hemi-aminal (2.37 g, $3.25 \mathrm{mmol}$ in theory) in a mixture $\mathrm{MeOH} / \mathrm{AcOH}(1: 1)(32 \mathrm{~mL})$ at room temperature was added $\mathrm{NaBH}_{3} \mathrm{CN}(2.15 \mathrm{~g}, 32.5 \mathrm{mmol})$. After $30 \mathrm{~min}$ stirring, the mixture was neutralized at $0{ }^{\circ} \mathrm{C}$ by addition of $\mathrm{H}_{2} \mathrm{O}(50 \mathrm{~mL})$ and $\mathrm{NaHCO}_{3}$ (until neutral $\mathrm{pH}, 250 \mathrm{~mL}$ ). The mixture was extracted with $\mathrm{Et}_{2} \mathrm{O}$ and the organic layers were washed with $\mathrm{H}_{2} \mathrm{O}$ and brine, dried $\left(\mathrm{MgSO}_{4}\right)$, filtered and the solvent removed under reduced pressure. The residue was purified by chromatography on silica gel (pentane/ $\mathrm{Et}_{2} \mathrm{O} 6: 4$ ) to give $921 \mathrm{mg}$ (50\% yield over two steps) of the required product $( \pm)-\mathbf{1 6}$ as a viscous colourless oil; ${ }^{1} \mathrm{H} \&{ }^{13} \mathrm{C}$ NMR: no data (presence of rotamer compounds).

\section{8. $5-\left(3 R^{*}\right)-5-\{N$-tert-Butyloxycarbonyl-3-[(tert- butyldiphenylsilyl)oxy]ethyl-pyrrolidin-4-one\}-2,2-dimethyl- 1,3-dioxane $( \pm)-17$}

Dess-Martin periodinane ( $823 \mathrm{mg}, 1.90 \mathrm{mmol}$ ) was added to a solution of alcohol $( \pm)-\mathbf{1 6}(722 \mathrm{mg}, 1.27 \mathrm{mmol})$ in $\mathrm{CH}_{2} \mathrm{Cl}_{2}(13 \mathrm{~mL})$. The mixture was stirred for $1 \mathrm{~h}$ at room temperature and then neutralized by addition of a mixture $\mathrm{NaHCO}_{3} / \mathrm{Na}_{2} \mathrm{~S}_{2} \mathrm{O}_{3} \quad(1: 1)$ $\left(7.0 \mathrm{~mL}\right.$ ). The mixture was extracted with $\mathrm{CH}_{2} \mathrm{Cl}_{2}$ and the organic layers were washed with $\mathrm{H}_{2} \mathrm{O}$, dried $\left(\mathrm{MgSO}_{4}\right)$, filtered and the solvent removed under reduced pressure. The residue was purified by chromatography on silica gel (pentane/ $/ \mathrm{Et}_{2} \mathrm{O} 6: 4$ ) to give $657 \mathrm{mg}$ (91\% yield) of the required product $( \pm)$-17 as a viscous colourless oil.

${ }^{1} \mathrm{H}$ NMR $\left(400 \mathrm{MHz}, \mathrm{CDCl}_{3}\right): \delta=7.66(\mathrm{~m}, 4 \mathrm{H}), 7.42(\mathrm{~m}, 6 \mathrm{H}), 4.04(\mathrm{t}$, $J=9.0 \mathrm{~Hz}, 2 \mathrm{H}), 3.76(\mathrm{~m}, 4 \mathrm{H}), 3.53(\mathrm{~d}, J=9.0 \mathrm{~Hz}, 2 \mathrm{H}), 3.17$ (t, $J=9.0 \mathrm{~Hz}$, $1 \mathrm{H}), 2.85(\mathrm{~m}, 1 \mathrm{H}), 2.19(\mathrm{~m}, 1 \mathrm{H}), 1.54(\mathrm{~m}, 12 \mathrm{H}), 1.49(\mathrm{~s}, 3 \mathrm{H}), 1.07(\mathrm{~s}, 9 \mathrm{H})$

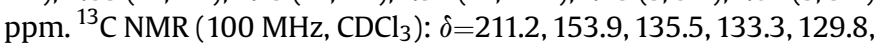
127.8, 99.2, 81.0, 65.9, 62.0; 62.0, 62.0, 48.2, 41.8, 31.4, 28.5, 28.5, $28.5,26.9,19.1 \mathrm{ppm}$. IR (thin film): $\nu=2932,2859,1756,1694,1473$, $1455,1428,1381,1366,1274,1231,1163,1103,997,965,908,862$, 824, 772, 729, 701, $687 \mathrm{~cm}^{-1}$. MS (40 eV, ES): $\mathrm{m} / z$ (\%): 606 (11) $[\mathrm{M}+\mathrm{K}]^{+}, 590$ (100) $[\mathrm{M}+\mathrm{Na}]^{+}$. ESI-HRMS: calcd for $\mathrm{C}_{32} \mathrm{H}_{45} \mathrm{NO}_{6} \mathrm{Si}$ $[\mathrm{M}+\mathrm{Na}]^{+}$590.2914; found 590.2912.

\section{9. $5-\left(3 S^{*}, 4 R^{*}\right)-5-\{N$-tert-Butyloxycarbonyl-3-[(tert- butyldiphenylsilyl)oxy]ethyl-4-hydroxy-4-methyl- pyrrolidine\}-2,2-dimethyl-1,3-dioxane ( \pm )-19}

Method with MeLi: A solution of MeLi (1.6 M in $\mathrm{Et}_{2} \mathrm{O}, 920 \mu \mathrm{L}$, $1.47 \mathrm{mmol}$ ) was added to a solution of ketone $( \pm)-17(167 \mathrm{mg}$, $0.29 \mathrm{mmol})$ in THF $(3.0 \mathrm{~mL})$. The mixture was stirred for $4 \mathrm{~h}$ at 
$-78{ }^{\circ} \mathrm{C}$, neutralized by addition of a $10 \%$ aqueous solution of $\mathrm{NaHSO}_{4}(5.0 \mathrm{~mL})$ and warmed up to room temperature. The mixture was extracted with $\mathrm{Et}_{2} \mathrm{O}$ and the organic layers were washed with $\mathrm{NaHCO}_{3}$ and brine, dried $\left(\mathrm{MgSO}_{4}\right)$, filtered and the solvent removed under reduced pressure. The residue was purified by chromatography on silica gel (pentane/ $\mathrm{Et}_{2} \mathrm{O} 7: 3$ ) to give the only non-desired diastereoisomer $( \pm)$-19 (70 $\mathbf{~ m g , ~ 4 1 \% ~ y i e l d ) ~ a s ~ a ~ v i s c o u s ~}$ colourless oil.

Method with $\mathrm{MeLi} / \mathrm{CeCl}_{3}$ : $\mathrm{CeCl}_{3} \cdot \mathrm{H}_{2} \mathrm{O}$ is prepared from $\mathrm{CeCl}_{3} \cdot 7 \mathrm{H}_{2} \mathrm{O}(1.36 \mathrm{~g}, 3.59 \mathrm{mmol})$ by drying under vacuum at $140{ }^{\circ} \mathrm{C}$ for $2 \mathrm{~h}$. After cooling down to room temperature, THF $(6.0 \mathrm{~mL})$ was added under argon atmosphere. A solution of MeLi (1.6 $\mathrm{M}$ in $\mathrm{Et}_{2} \mathrm{O}$, $4.5 \mathrm{~mL}, 7.18 \mathrm{mmol}$ ) was then added at $-78^{\circ} \mathrm{C}$ and the mixture was stirred for $1 \mathrm{~h}$ at $-78{ }^{\circ} \mathrm{C}$ before a solution of ketone $( \pm)-\mathbf{1 7}(309 \mathrm{mg}$, $0.54 \mathrm{mmol})$ in THF $(12 \mathrm{~mL})$ was introduced to the mixture. The reaction was stirred for $2 \mathrm{~h}$ at $-78^{\circ} \mathrm{C}$ and neutralized by addition of $\mathrm{NH}_{4} \mathrm{Cl}(15 \mathrm{~mL})$. After warming up to room temperature, the mixture was extracted with $\mathrm{Et}_{2} \mathrm{O}$ and the organic layers were washed with brine, dried $\left(\mathrm{MgSO}_{4}\right)$, filtered and the solvent removed under reduced pressure. The residue was purified by chromatography on silica gel (pentane/ $\mathrm{Et}_{2} \mathrm{O}$ 7:3) to give the only diastereoisomer $( \pm)$-19 (207 mg, 65\% yield) as a viscous colourless oil.

${ }^{1} \mathrm{H}$ NMR (400 MHz, $\left.\mathrm{CDCl}_{3}\right): \delta=7.66(\mathrm{~m}, 4 \mathrm{H}), 7.41(\mathrm{~m}, 6 \mathrm{H}), 4.07$ (dd, $J=12.0 / 4.8 \mathrm{~Hz}, 2 \mathrm{H}$ ), 3.83 (dd, $J=12.0 / 8.0 \mathrm{~Hz}, 2 \mathrm{H}$ ), 3.72 (t, $J=5.6 \mathrm{~Hz}, 2 \mathrm{H}$ ), 3.55 (dd, $J=11.2 / 8.8 \mathrm{~Hz}, 1 \mathrm{H}$ ), 2.80 (dd, $J=11.2 / 11.2 \mathrm{~Hz}$, $1 \mathrm{H}), 2.38(\mathrm{~m}, 1 \mathrm{H}), 2.17(\mathrm{~s}, 6 \mathrm{H}), 1.83(\mathrm{~m}, 1 \mathrm{H}), 1.43(\mathrm{~s}, 10 \mathrm{H}), 1.05(\mathrm{~s}, 9 \mathrm{H})$, $1.01(\mathrm{~s}, 3 \mathrm{H}) \mathrm{ppm} .{ }^{13} \mathrm{C} \mathrm{NMR}\left(100 \mathrm{MHz}, \mathrm{CDCl}_{3}\right): \delta=153.6,135.5,133.7$, 129.6, 127.6, 98.8, 81.1, 79.8, 63.6, 61.9, 60.9, 59.5, 51.1, 43.7, 29.9, 28.7, 28.5, 26.9, 19.4, $19.1 \mathrm{ppm}$. IR (thin film): $\nu=3363,2931,2858$, 1666, 1473, 1428, 1392, 1367, 1255, 1162, 1110, 1085, 1007, 939, 909, 857, 823, 734, 701, $688 \mathrm{~cm}^{-1}$. MS (30 eV, ES): $\mathrm{m} / z$ (\%): 583 (9) $[\mathrm{M}+\mathrm{H}]^{+}, \quad 566(100) \quad\left[\mathrm{M}+\mathrm{Na}-\left(\mathrm{CH}_{3}\right)_{2} \mathrm{CO}\right]^{+}, \quad 544$ (46) $[\mathrm{M}+\mathrm{H}-$ $\left(\mathrm{CH}_{3}\right)_{2} \mathrm{CO}^{+}, 488$ (12), 444 (16), 214 (10). ESI-HRMS: calcd for $\mathrm{C}_{33} \mathrm{H}_{49} \mathrm{NO}_{6} \mathrm{Si}\left[\mathrm{M}-\left(\mathrm{CH}_{3}\right)_{2} \mathrm{CO}+\mathrm{Na}\right]^{+}$566.2914; found 566.2936.

\subsection{0. $5-\left(3 S^{*}, 4 R^{*}\right)-5-\{N$-tert-Butyloxycarbonyl-3-[(tert- butyldiphenylsilyl)oxy]ethyl-4-hydroxy-4-methyl-pyrrolidin- 2-one\}-2,2-dimethyl-1,3-dioxane ( \pm )-20}

To a stirred solution of pyrrolidine $( \pm)-\mathbf{1 9}(107 \mathrm{mg}, 0.18 \mathrm{mmol})$ in a mixture AcOEt/ $\mathrm{H}_{2} \mathrm{O}(2: 1)(3.0 \mathrm{~mL})$ were added sodium hydrogenocarbonate ( $100 \mathrm{mg}, 1.19 \mathrm{mmol}$ ) and sodium periodate $(198 \mathrm{mg}$, $0.92 \mathrm{mmol})$. After $15 \mathrm{~min}$ of vigorous stirring, ruthenium chloride hydrate (38 mg, $0.07 \mathrm{mmol}$ ) was added. Following $40 \mathrm{~h}$ of stirring at room temperature, brine $(3.0 \mathrm{~mL})$ was added and the product was extracted with $\mathrm{CH}_{2} \mathrm{Cl}_{2}$. The organic layers were combined and washed with $\mathrm{H}_{2} \mathrm{O}$ and brine, dried $\left(\mathrm{MgSO}_{4}\right)$, filtered and the solvent removed under reduced pressure. The residue was purified by chromatography on silica gel (pentane/ $\mathrm{Et}_{2} \mathrm{O} 6: 4$ ) to give the required product $( \pm)-\mathbf{2 0}$ (57 $\mathrm{mg}, 52 \%$ yield) as a viscous colourless oil.

${ }^{1} \mathrm{H}$ NMR (400 MHz, $\left.\mathrm{CDCl}_{3}\right): \delta=7.71(\mathrm{~m}, 4 \mathrm{H}), 7.42(\mathrm{~m}, 6 \mathrm{H}), 4.63(\mathrm{~d}$, $J=12.3 \mathrm{~Hz}, 1 \mathrm{H}), 4.48(\mathrm{~d}, J=11.6 \mathrm{~Hz}, 1 \mathrm{H}), 4.16(\mathrm{dd}, J=11.6 / 1.5 \mathrm{~Hz}, 1 \mathrm{H})$, 4.04 (s large, $1 \mathrm{H}$ ), 3.97 (dd, $J=12.3 / 1.5 \mathrm{~Hz}, 1 \mathrm{H}$ ), 3.95 (ddd, $J=7.2 / 6.2$ / $2.3 \mathrm{~Hz}, 2 \mathrm{H}$ ), 2.67 (ddd, $J=7.0 / 6.9 / 2.3 \mathrm{~Hz}, 1 \mathrm{H}$ ), 2.01 (ddd, $J=14.0 / 6.9 /$ $6.2 \mathrm{~Hz}, 1 \mathrm{H}$ ), 1.82 (ddd, $J=14.0 / 7.2 / 7.0 \mathrm{~Hz}, 1 \mathrm{H}), 1.59$ (s, 3H), 1.56 (s, $9 \mathrm{H}), 1.44(\mathrm{~s}, 3 \mathrm{H}), 1.26(\mathrm{~s}, 3 \mathrm{H}), 1.08(\mathrm{~s}, 9 \mathrm{H}) \mathrm{ppm} .{ }^{13} \mathrm{C}$ NMR $(100 \mathrm{MHz}$, $\left.\mathrm{CDCl}_{3}\right): \delta=172.9,150.3,135.6,133.7,129.7,127.7,99.7,84.1,77.4,62.1$, 61.8, 60.6, 60.5, 48.3, 28.1, 27.7, 26.9, 26.8, 20.8, 19.7, 19.2 ppm.

\subsection{1. $5-\left(3 S^{*}, 4 R^{*}\right)-5-\{N$-tert-Butyloxycarbonyl-3-[( $p$ - nitrobenzoyl)oxy]ethyl-4-hydroxy-4-methyl-pyrrolidine\}-2,2- dimethyl-1,3-dioxane ( \pm )-21}

To a stirred solution of pyrrolidine $( \pm)-\mathbf{1 9}(200 \mathrm{mg}, 0.34 \mathrm{mmol})$ in THF ( $4.3 \mathrm{~mL})$ was added tetrabutylammonium fluoride trihydrate (162 mg, $0.51 \mathrm{mmol}$ ). After $30 \mathrm{~min}$ of stirring at room temperature,
$\mathrm{NH}_{4} \mathrm{Cl}(4.0 \mathrm{~mL})$ was added and the product was extracted with AcOEt. The organic layers were combined and washed with $\mathrm{H}_{2} \mathrm{O}$ and brine, dried $\left(\mathrm{MgSO}_{4}\right)$, filtered and the solvent removed under reduced pressure.

To a stirred solution of the previous product ( $73 \mathrm{mg}, 0.21 \mathrm{mmol}$ ) in $\mathrm{CH}_{2} \mathrm{Cl}_{2}(2.0 \mathrm{~mL})$ were added triethylamine $(95 \mu \mathrm{L}, 0.67 \mathrm{mmol})$, DMAP (1.3 mg, $0.01 \mathrm{mmol}$ ) and a solution of 4-nitrobenzoyl chloride (59 $\mathrm{mg}, 0.32 \mathrm{mmol}$ ) in $\mathrm{CH}_{2} \mathrm{Cl}_{2}(1.0 \mathrm{~mL})$. After $1 \mathrm{~h}$ stirring at room temperature, $\mathrm{NH}_{4} \mathrm{Cl}(2.0 \mathrm{~mL})$ was added and the product was extracted with $\mathrm{CH}_{2} \mathrm{Cl}_{2}$. The organic layers were combined and washed with $\mathrm{H}_{2} \mathrm{O}$ and brine, dried $\left(\mathrm{MgSO}_{4}\right)$, filtered and the solvent removed under reduced pressure. The residue was purified by chromatography on silica gel (pentane/AcOEt 1:1) to give the required product $( \pm)$-21 (80 $\mathrm{mg}, 61 \%$ yield over two steps) as colourless crystals.

${ }^{1} \mathrm{H}$ NMR (400 MHz, $\left.\mathrm{CDCl}_{3}\right): \delta=8.24(\mathrm{~m}, 4 \mathrm{H}), 5.14(\mathrm{~d}, J=12.0 \mathrm{~Hz}$, $1 \mathrm{H}), 4.67(\mathrm{~d}, J=12.0 \mathrm{~Hz}, 1 \mathrm{H}), 4.54(\mathrm{~m}, 1 \mathrm{H}), 4.42(\mathrm{dd}, J=6.9 / 6.9 \mathrm{~Hz}$, $1 \mathrm{H}), 4.35$ (s large, $1 \mathrm{H}), 3.91(\mathrm{~d}, J=12.0 \mathrm{~Hz}, 1 \mathrm{H}), 3.78(\mathrm{~d}, J=12.0 \mathrm{~Hz}$, 1H), $3.62(\mathrm{~m}, 1 \mathrm{H}), 2.79(\mathrm{dd}, J=11.7 / 10.8 \mathrm{~Hz}, 1 \mathrm{H}), 2.33(\mathrm{~m}, 1 \mathrm{H}), 2.11$ (m, 1H), $1.75(\mathrm{~m}, 1 \mathrm{H}), 1.65(\mathrm{~s}, 3 \mathrm{H}), 1.52(\mathrm{~s}, 3 \mathrm{H}), 1.39(\mathrm{~s}, 9 \mathrm{H}), 1.33$ (s, 3H) ppm. ${ }^{13} \mathrm{C}$ NMR $\left(100 \mathrm{MHz}, \mathrm{CDCl}_{3}\right): \delta=164.5,150.5,135.5,130.6$, $123.5,119.9,98.8,81.0,80.0,65.2,61.8,60.8,59.6,50.4,43.1,34.1$, 28.3, 26.1, 22.3, $14.0 \mathrm{ppm}$.

\subsection{2. $5-\left(3 S^{*}, 4 S^{*}\right)-5-\{N$-tert-Butyloxycarbonyl-3-[(tert- butyldiphenylsilyl)oxy]ethyl-4-hydroxy-4-methyl- pyrrolidine\}-2,2-dimethyl-1,3-dioxane $( \pm)-18$}

Trimethylsulfoxonium iodide $\left(\mathrm{Me}_{3} \mathrm{SOI}\right)(140 \mathrm{mg}, 0.62 \mathrm{mmol})$ was added to a solution of $\mathrm{NaH}(25 \mathrm{mg}, 0.62 \mathrm{mmol}$ ) (washed two times with $0.5 \mathrm{~mL}$ of distillated cyclohexane) in DMSO $(1.2 \mathrm{~mL})$. After $30 \mathrm{~min}$ stirring at room temperature, neat ketone $( \pm)-\mathbf{1 7}$ ( $70 \mathrm{mg}, 0.12 \mathrm{mmol}$ ) was added in one portion and the mixture was heated at $60^{\circ} \mathrm{C}$ for $1.5 \mathrm{~h}$. After cooling down, the reacting mixture was then neutralized at $0{ }^{\circ} \mathrm{C}$ by addition of $\mathrm{H}_{2} \mathrm{O}(1.0 \mathrm{~mL})$ and then extracted with $\mathrm{Et}_{2} \mathrm{O}$. The combined organic layers were washed with $\mathrm{H}_{2} \mathrm{O}$ and brine, dried $\left(\mathrm{MgSO}_{4}\right)$, filtered and the solvent removed under reduced pressure.

To a stirred solution of the previous crude product in $\mathrm{Et}_{2} \mathrm{O}$ $(0.5 \mathrm{~mL})$ at $0{ }^{\circ} \mathrm{C}$ was added a solution of $\mathrm{LiAlH}_{4}\left(1.0 \mathrm{M}\right.$ in $\mathrm{Et}_{2} \mathrm{O}, 90 \mu \mathrm{L}$, $0.09 \mathrm{mmol}$ ). The resulting mixture was allowed to warm up to room temperature and stirred over $30 \mathrm{~min}$ before 2-propanol $(400 \mu \mathrm{L})$ was added at $0{ }^{\circ} \mathrm{C}$. The resulting mixture was filtered through a pad of Celite ${ }^{\circledR}$ and concentrated under reduced pressure. The residue was purified by chromatography on silica gel (pentane/Et $\mathrm{E}_{2} \mathrm{O} 1: 1$ ) to give the required diastereoisomer $( \pm)-\mathbf{1 8}(37 \mathrm{mg}, 52 \%$ yield over two steps) as a viscous colourless oil.

${ }^{1} \mathrm{H}$ NMR (400 MHz, $\left.\mathrm{CDCl}_{3}\right): \delta=7.65(\mathrm{~m}, 4 \mathrm{H}), 7.41(\mathrm{~m}, 6 \mathrm{H}), 4.11(\mathrm{~d}$, $J=12.8 \mathrm{~Hz}, 1 \mathrm{H}), 3.94(\mathrm{~d}, J=12.8 \mathrm{~Hz}, 1 \mathrm{H}), 3.85(\mathrm{~d}, J=12.0 \mathrm{~Hz}, 1 \mathrm{H}), 3.72$ (m, 1H), $3.65(\mathrm{~m}, 1 \mathrm{H}), 3.49(\mathrm{~m}, 1 \mathrm{H}), 3.44(\mathrm{~d}, J=12.0 \mathrm{~Hz}, 1 \mathrm{H}), 3.09(\mathrm{t}$, $J=11.2 \mathrm{~Hz}, 1 \mathrm{H}), 2.17(\mathrm{~s}, 6 \mathrm{H}), 2.10(\mathrm{~m}, 1 \mathrm{H}), 1.72(\mathrm{~m}, 1 \mathrm{H}), 1.57(\mathrm{~m}, 1 \mathrm{H})$, $1.45(\mathrm{~s}, 9 \mathrm{H}), 1.33(\mathrm{~s}, 3 \mathrm{H}), 1.05(\mathrm{~s}, 9 \mathrm{H}) \mathrm{ppm} .{ }^{13} \mathrm{C}$ NMR $(100 \mathrm{MHz}$, $\left.\mathrm{CDCl}_{3}\right): \delta=156.2,135.5,133.4,129.8,127.7,98.0,82.4,80.6,63.5$, $63.4,62.9,62.5,51.1,41.9,30.9,29.2,28.5,27.9,20.5,19.1$ ppm. IR (thin film): $\nu=3403,3071,2931,2858,1664,1473,1428,1403,1367$, $1256,1169,1111,1006,911,858,823,775,737,702 \mathrm{~cm}^{-1}$. MS $(30 \mathrm{eV}$, ES): $m / z(\%): 606(15)[\mathrm{M}+\mathrm{Na}]^{+}, 583(5)[\mathrm{M}+\mathrm{H}]^{+}, 566(100)$ $\left[\mathrm{M}+\mathrm{Na}-\left(\mathrm{CH}_{3}\right)_{2} \mathrm{CO}\right]^{+}, 544(12)\left[\mathrm{M}+\mathrm{H}-\left(\mathrm{CH}_{3}\right)_{2} \mathrm{CO}\right]^{+}, 488(8), 444$ (12), 236 (5), 219 (11), 214 (15). ESI-HRMS: calcd for $\mathrm{C}_{33} \mathrm{H}_{49} \mathrm{NO}_{6} \mathrm{Si}$ $\left[\mathrm{M}-\left(\mathrm{CH}_{3}\right)_{2} \mathrm{CO}+\mathrm{Na}\right]^{+}$566.2914; found 566.2924.

\section{Acknowledgements}

J.B. thanks ANR for a post-doctoral fellowship. We thank Elise Prost for assistance with NMR experiments 
This work was partly supported by grants from the Swedish Research Council (Grants 621-2009-4736 and 622-2009-371). S.S. thanks the Wenner-Gren Foundations for a postdoctoral fellowship. Computer time was generously provided by the PDC Center for High Performance Computing.

\section{Supplementary data}

Supplementary data associated with this article can be found, in the online version,

\section{References and notes}

1. For the isolation and biology of salinosporamide A, see: (a) Feling, R. H.; Buchanan, G. O.; Mincer, T. J.; Kauffman, C. A.; Jensen, P. R.; Fenical, W. Angew. Chem. 2003, 115, 369-371; Angew. Chem., Int. Ed. 2003, 42, 355-357; (b) Chauhan, D.; Catley, L.; Li, G.; Podar, K.; Hideshima, T.; Velankar, M.; Mitsiades, C.; Mitsiades, N.; Yasui, H.; Letai, A.; Ovaa, H.; Berkers, C.; Nicholson, B.; Chao, T.-H.; Neuteboom, S. T. C.; Richardson, P.; Palladino, M. A.; Anderson, K. C. Cancer Cell 2005, 8, 407-419; (c) Groll, M.; Huber, R.; Potts, B. C. M. J. Am. Chem. Soc. 2006, 128, 5136-5141; (d) Beer, L. L.; Moore, B. S. Org. Lett. 2007, 9, 845-848; (e) Fenical, W.; Jensen, P. R.; Palladino, M. A.; Lam, K. S.; Lloyd, G. K.; Potts, B. C. Bioorg. Med. Chem. 2009, 17, 2175-2180; (f) Obaidat, A.; Weiss, J.; Wahlgren, B.; Manam, R. R.; Macherla, V. R.; McArthur, K.; Chao, T.-H.; Palladino, M. A.; Lloyd, G. K.; Potts, B. C.; Enna, S. J.; Neuteboom, S. T. C.; Hagenbuch, B. J. Pharmacol. Exp. Ther. 2011, 337, 479-486.

2. Salinosporamide syntheses: for reviews see: (a) Gulder, T. A.; Moore, B. S. Angew. Chem., Int. Ed. 2010, 49, 9346-9367; (b) Potts, B. C.; Lam, K. S. Mar. Drugs 2010, 8, 835-880; (c) Shibasaki, M.; Kanai, M.; Fukuda, N. Chem.-Asian. J. 2007, $2,20-38$.

3. Enantioselectivesalinosporamide syntheses: (a) Reddy, L. R.; Saranavan, P.; Corey, E. J. J. Am. Chem. Soc. 2004, 126, 6230-6231; (b) Endo, A.; Danishefsky, S. J. J. Am. Chem. Soc. 2005, 127, 8298-8299; (c) Reddy, L. R.; Fournier, J.-F.; Reddy, B. V. S.; Corey, E. J. Org. Lett. 2005, 7, 2699-2701; (d) Ling, T.; Macherla, V. R.; Manam, R. R.; McArthur, K. A.; Potts, B. C. M. Org. Lett. 2007, 9, 2289-2292; (e) Takahashi, K.; Midori, M.; Kawano, K.; Ishihara, J.; Hatakeyama, S. Angew. Chem. 2008, 120, 6340-6342; Angew. Chem., Int. Ed. 2008, 47, 6244-6246; (f) Fukuda, T.; Sugiyama, K.; Arima, S.; Harigaya, Y.; Nagamitsu, T.; Omura, S. Org. Lett. 2008, 10, 4239-4242; (g) Nguyen, H.; Ma, G.; Romo, D. Chem. Commun. 2010, 4803-4805; (h) Sato, H.; Fukuda, H.; Tomizawa, M.; Masaki, T.; Shibuya, M.; Kanoh, N.; Iwabuchi, Y. Heterocycles 2010, 81, 2239-2246; (i) Nguyen, H.; Ma, G.; Gladysheva, T.; Fremgen, T.; Romo, D. J. Org. Chem. 2011, 76, 2-12; (j) Kaiya, Y.; Hasegawa, J.; Mormose, T.; Sato, T.; Chida, N. Chem.-Asian. J. 2011, 6, 209-219; (k) Satoh, N.; Yotoshima, S.; Fukuyama, T. Org. Lett. 2011, 13, 3028-3031 For racemic syntheses, see: (1) Mulholland, N. P.; Pattenden, G.; Walters, I. A. S. Org. Biomol. Chem. 2006, 4, 2845-2846; (m) Mulholland, N. P.; Pattenden, G.; Walters, I. A. S. Org. Biomol. Chem. 2008, 6, 2782-2789; (n) Ma, G.; Nguyen, H.; Romo, D. Org. Lett. 2007, 9, 2143-2146.

4. Formal salinosporamide syntheses: (a) Caubert, V.; Massé, J.; Retailleau, P.; Langlois, N. Tetrahedron Lett. 2007, 48, 381-384; (b) Margalef, I. V.; Rupnicki, L.; Lam, H. W. Tetrahedron 2008, 64, 7896-7901; (c) Momose, T.; Kaiya, Y.; Hama, N.; Hasegawa, J.; Sato, T.; Chida, N. Synthesis 2009, 2983-2991; (d) Mosey, R. A.; Tepe, J. J. Tetrahedron Lett. 2009, 50, 295-297; (e) Struble, J. R.; Bode, J. W. Tetrahedron 2009, 65, 4957-4967; (f) Ling, T.; Potts, B. C.; Macherla, V. R. J. Org. Chem. 2010, 75, 3882-3885.

5. With the exception of Chida synthesis, which employed a D-arabinose derivative as starting material in Refs. $3 \mathrm{j}, 4 \mathrm{c}$.

6. Hoppe allylation: For a recent review see: (a) Hoppe, D. Synthesis 2009, 43-55 For crotyltitanation of aldehydes from primary crotylcarbamates see: (b) Hoppe, D. Angew. Chem. 1984, 96, 930-946; Angew. Chem., Int. Ed. Engl. 1984, 23, 932-948; (c) Hoppe, D.; Zschage, O. Angew. Chem. 1989, 101, 67-69; Angew. Chem., Int. Ed. Engl. 1989, 28, 69-71; (d) Hoppe, D.; Zschage, O. Tetrahedron 1992, 48, 8389-8392; Hoppe, D.; Hense, T. Angew. Chem. 1997, 109, 2376-2410; Angew. Chem., Int. Ed. 1997, 36, 2282-2316; (e) Fargeas, V.; Le Ménez, P.; Berque, I.; Ardisson, J.; Pancrazi, A. Tetrahedron 1996, 52, 6613-6634; (f) Berque, I.; Le Ménez, P.; Razon, P.; Anies, C.; Pancrazi, A.; Ardisson, J.; Neuman, A.; Prangé, T.; Brion, J.-D. Synlett 1998, 1132-1134; (g) Berque, I.; Le Ménez, P.; Razon, P.; Pancrazi, A.; Ardisson, J.; Brion, J.-D. Synlett 1998, 1135-1137; (h) Berque, I.; Le Ménez, P.; Razon, P.; Mahuteau, J.; Férézou, J.-P.; Pancrazi, A.; Ardisson, J.; Brion, J.-D. J. Org. Chem. 1999, 64, 373-381; (i) De Lemos, E.; Porée, F. H.; Commerçon, A.; Betzer, J.-F.; Pancrazi, A.; Ardisson, J. Angew. Chem. 2007, 48, 9509-9600; Angew. Chem., Int. Ed. 2007, 46, 1917-1921; (j) De Lemos, E.; Porée, F. H.; Bourin, A.; Barbion, J.; Agouridas, E.; Lannou, M.-I.; Commerçon, A.; Betzer, J.-F.; Pancrazi, A.; Ardisson, J. Chem.-Eur. J. 2008, 14, 11092-11112; (k) De Lemos, E.; Agouridas, E.; Sorin, G.; Guerreiro, A.; Commerçon, A.; Pancrazi, A.; Betzer, J.-F.; Lannou, M.-I.; Ardisson, J. Chem.-Eur. J. 2011, 17, 10123-10134.

7. Hoppe allylation: for crotyltitanation of aldehydes from racemic secondary crotylcarbamates see: (a) Zschage, O.; Schwark, J. R.; Hoppe, D. Angew. Chem. 1990, 29, 336-337; Angew. Chem., Int. Ed. Engl. 1990, 29, 296-298; (b) Zschage, O.; Schwark, J. R.; Krämer, T.; Hoppe, D. Tetrahedron 1992, 48, 8377-8388 For crotyltitanation of aldehydes from optically active secondary crotylcarbamates see: (c) Hoppe, D.; Krämer, T. Angew. Chem. 1986, 29, 171-173; Angew. Chem.,
Int. Ed. Engl. 1986, 25, 160-162; (d) Krämer, T.; Hoppe, D. Tetrahedron Lett. 1987, 28, 5149-5152; (e) Krämer, T.; Scharwark, J.-R.; Hoppe, D. Tetrahedron Lett. 1989, 30, 7037-7040; (f) Schwark, J. R.; Hoppe, D. Synthesis 1990, 291-294; (g) See Ref. 6d. For allyltitanation of aldehydes from optically active aliphatic secondary allylcarbamates see: (h) Razon, P.; Dhulut, S.; Bezzenine-Lafollée, S.; Courtieu, J.; Pancrazi, A.; Ardisson, J. Synthesis 2005, 102-108; (i) Razon, P.; N'Zoutani, M.-A.; Dhulut, S.; Bezzenine-Lafollée, S.; Courtieu, J.; Pancrazi, A.; Ardisson, J. Synthesis 2005, 109-121 For allyltitanation of aldehydes from optically active cyclic secondary allylcarbamates see: (j) Becker, J.; Grimme, S.; Frölich, R.; Hoppe, D. Angew. Chem. 2007, 119, 1672-1676; Angew. Chem., Int. Ed. 2007, 46, 1645-1649; (k) Becker, J.; Frölich, R.; Kataeva, O.; Hoppe, D. Eur. J. Org. Chem. 2007, 3349-3364; (1) Becker, J.; Bergander, K.; Frölich, R.; Hoppe, D. Angew. Chem. 2008, 120, 1678-1681; Angew. Chem., Int. Ed. 2008, 47, 1654-1657; (m) Hémery, T.; Becker, J.; Frölich, R.; Hoppe, D. Eur. J. Org. Chem. 2010, 3711-3720; (n) Hémery, T.; Wibbeling, B.; Frölich, R.; Hoppe, D. Synthesis 2010, 329-342; (o) Duhlut, S.; Bourin, A.; Lannou, M.-I.; Fleury, E.; Lensen, N.; Chelain, E.; Pancrazi, A.; Ardisson, J.; Fahy, J. Eur. J. Org. Chem. 2007, 5235-5243. 8. Ooi, H.; Ishibashi, N.; Iwabuchi, Y.; Ishihara, J.; Hatakeyama, S. J. Org. Chem. 2004, 69, 7765-7768.

9. Earlier investigations relied on the simultaneous control of C2 and C3 centres through allylation reaction of the corresponding bulky methylketone with allylcarbamate $( \pm)-\mathbf{1 1}$, under Hoppe conditions, have been conducted to provide directly the desired racemic homoallylic alcohol. Unfortunately, despite several attempts, no reaction occurred; the starting material was recovered along with degradation products. The methylketone was smoothly obtained from aldehyde $\mathbf{1 3}$ by methylation and subsequent Swern oxidation.

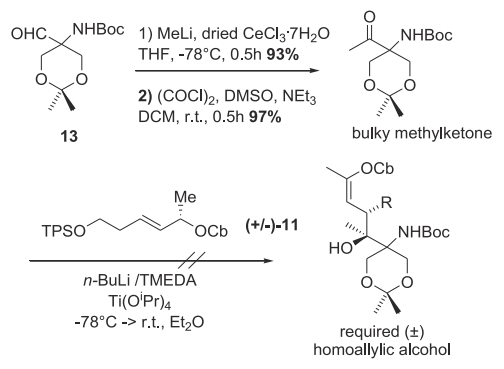

10.

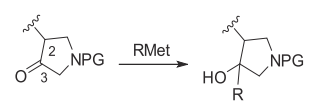

Methylation of pyrrolidin-3-ones (salinosporamide numbering): Monosubstituted at C2, C1 or C4: (a) De Weerd, P. (Novartis AG, CH-4002 Basel, CH) WO/2006/066896, PTC/EP2005/013786; (b) Davis, F. A.; Ramachandar, T.; Liu, H. Org. Lett. 2004, 6, 3393-3395; (c) Del Valle, J. R.; Goodman, M. Angew. Chem., Int. Ed. 2002, 41, 1600-16002; (d) Haddad, M.; Larchevêque, M. Tetrahedron: Asymmetry 2005, 16, 2243-2247; (e) Krapcho, J.; Turk, C.; Cushman, D. W.; Powell, J. R.; DeForrest, J. M.; Spitzmiller, E. R.; Karanewsky, D. S.; Duggan, M.; Rovnvak, G.; Scharwatz, J.; Natarajan, S.; Godfrey, J. D.; Ryono, D. E.; Neubeck, R.; Atwa, K. S.; Petrillo, E. W., Jr. J. Med. Chem. 1988, 31, 1148-1160; (f) Ma, Z.; Hu, H.; Xiong, W.; Zhai, H. Tetrahedron 2007, 63, 7523-7531; (g) Chang, M.-Y.; Pai, C.-L.; Chen, H.-P. Tetrahedron Lett. 2005, 46, 7705-7709 Polysubstituted: (h) Baldwin, J. E.; Bamford, S. J.; Fryer, A. M. Tetrahedron 1997, 53, 5233-5254; (i) Ma, D.; Wu, W.; Deng, P. Tetrahedron Lett. 2001, 42, 6929-6931; (j) Gupta, S.; Schafmeister, C. E. J. Org. Chem. 2009, 74, 3652-3658; (k) Blanco, M.-J.; Sardina, F. J. J. Org. Chem. 1998, 63, 3411-3434; (l) Davis, F. A.; Xu, H.; Wu, Y.; Zhang, J. Org. Lett. 2006, 8 , 2273-2276 Chelate formation: (m) Molonay, M. G.; Yaqoob, M. Synlett 2004, 1631-1633; (n) Ooi, T.; Miki, T.; Maruoka, K. Org. Lett. 2005, 7, 191-193; (o) Moreau, R. J.; Sorensen, E. J. Tetrahedron 2007, 63, 6446-6453; (p) Donohoe, T. J.; Chiu, J. Y. K.; Thomas, R. E. Org. Lett. 2007, 9, 421-424.

11. The structure was built using Sybyl-X (Tripos, Inc., St. Louis, Missouri, USA), then optimized by energy minimization in the Tripos force field. Conformational sampling was performed using Omega2 (Open Eye Scientific software, Inc., Santa Fe, New Mexico, USA) to generate 200 low energy conformers.

12. Applications of $\mathrm{CeCl}_{3}$ : (a) Bartoli, G.; Marcantoni, E.; Marcolini, M.; Sambri, L Chem. Rev. 2010, 110, 6104-6143; (b) Imamoto, T.; Takiyama, N.; Nakamura, K.; Hatajima, T.; Kamiya, Y. J. Am. Chem. Soc. 1989, 111, 4392-4398 Catalytic synthesis of tertiary alcohol from ketones with organometallic reagents: (c) Hatano, M.; Ishihara, K. Synthesis 2008, 1647-1675 Enantioselective catalytic formation of quaternary stereogenic centers: (d) Cozzi, P. G.; Hilgraf, R.; Zimmermann, N. Eur. J. Org. Chem. 2007, 5969-5994.

13. (a) Mohapatra, D. K.; Mondal, D.; Gonnade, R. G.; Chorghade, M. S.; Gurjar, M. K. Tetrahedron Lett. 2006, 47, 6031-6035; (b) Han, J.-S.; Lowary, T. L. J. Org. Chem. 2003, 68, 4116-4119.

14. To overcome this unfavourable diastereoselectivity, different methylation conditions of ketones without spiroketal moiety were screened without any satisfactory result. 


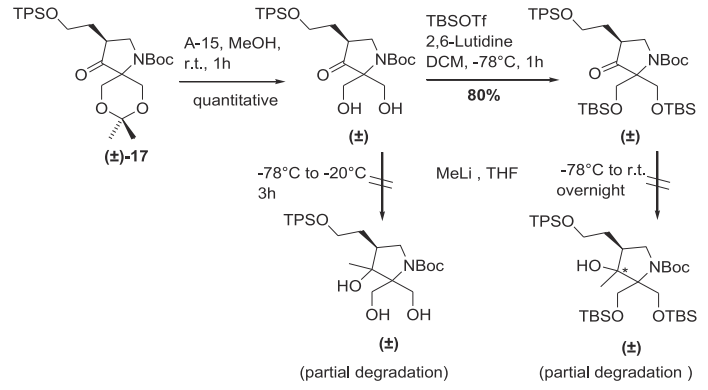

15. The methylation of a corresponding linear ketone provided a mixture of two diastereomers. The required alcohol was obtained in a rather low $20 \%$ yield, the main isolated product being the unwanted diastereomer.

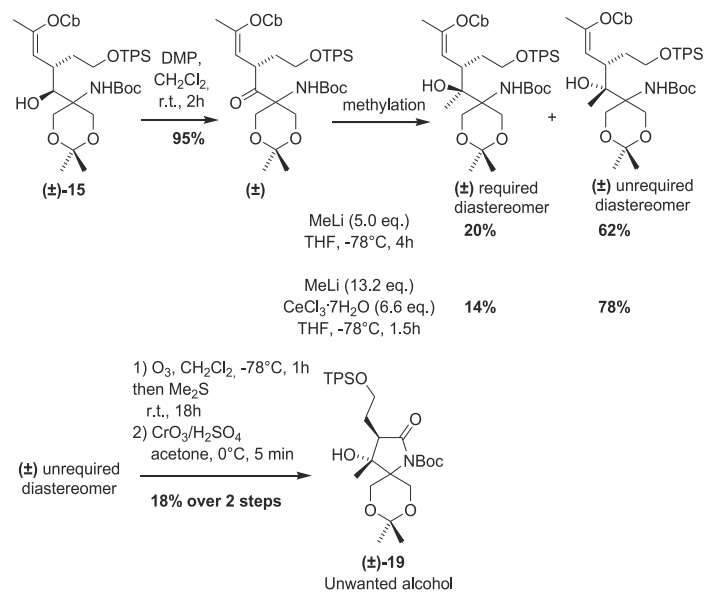

16. Attempts to oxidize the lactam resulting from $( \pm)-\mathbf{1 6}$ were unsuccessful leading mainly to the decomposition of the starting material. Therefore, the methylation of the expected ketone could not be studied.

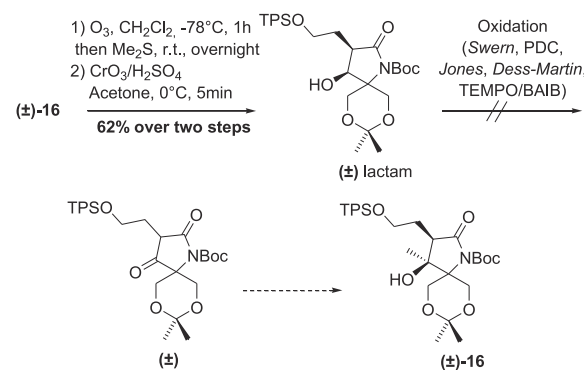

17. Stereoselective facial addition of the methyl group in presence of dimethylzinc and optically active ligands was studied on pyrrolidinone $( \pm)-\mathbf{1 7}$ and linear ketone corresponding to ( \pm )-15 (cf. Ref. 15) under various conditions $\left(\mathrm{Me}_{2} \mathrm{Zn}\right.$ with additives: prolinol, ephedrine, TADDOL) Ref. 12c,d; however, all attempts were ineffective: no reaction occurred, the starting material was recovered along with degradation products.

18. Corey, E. J.; Chaykovsky, M. J. Am. Chem. Soc. 1965, 87, 1353-1364.

19. (a) Lee, C.; Yang, W.; Parr, R. G. Phys. Rev. B: Condens. Matter 1988, 37, 785-789; (b) Becke, A. D. Phys. Rev. A: At., Mol., Opt. Phys. 1988, 38, 3098-3100; (c) Becke, A. D. J. Chem. Phys. 1992, 96, 2155-2160; (d) Becke, A. D. J. Chem. Phys. 1992, 97 9173-9177; (e) Becke, A. D. J. Chem. Phys. 1993, 98, 5648-5652.

20. Frisch, M. J.; Trucks, G. W.; Schlegel, H. B.; Scuseria, G. E.; Robb, M. A.; Cheeseman, J R.; Montgomery, J. A., Jr.; Vreven, T.; Kudin, K. N.; Burant, J. C.; Millam, J. M.; Iyengar, S. S.; Tomasi, J.; Barone, V.; Mennucci, B.; Cossi, M.; Scalmani, G.; Rega, N. Petersson, G. A.; Nakatsuji, H.; Hada, M.; Ehara, M.; Toyota, K.; Fukuda, R.; Hasegawa, J.; Ishida, M.; Nakajima, T.; Honda, Y.; Kitao, O.; Nakai, H.; Klene, M.; Li, X.; Knox, J. E.; Hratchian, H. P.; Cross, J. B.; Bakken, V.; Adamo, C.; Jaramillo, J.; Gomperts, R.; Stratmann, R. E.; Yazyev, O.; Austin, A. J.; Cammi, R.; Pomelli, C.; Ochterski, J. W.; Ayala, P. Y.; Morokuma, K.; Voth, G. A.; Salvador, P.; Dannenberg, J. J.; Zakrzewski, V. G.; Dapprich, S.; Daniels, A. D.; Strain, M. C.; Farkas, O.; Malick, D. K.; Rabuck, A. D.; Raghavachari, K.; Foresman, J. B.; Ortiz, J. V.; Cui, Q.; Baboul, A. G.; Clifford, S.; Cioslowski, J.; Stefanov, B. B.; Liu, G.; Liashenko, A.; Piskorz, P.; Komaromi, I.; Martin, R. L.; Fox, D. J.; Keith, T.; Al-Laham, M. A.; Peng, C. Y.; Nanayakkara, A.; Challacombe, M.; Gill, P. M. W.; Johnson, B.; Chen, W.; Wong, M. W.; Gonzalez, C.; Pople, J. A. Gaussian 03, Revision D.01; Gaussian: Wallingford, CT, 2004.

21. (a) Barone, V.; Cossi, M. J. Phys. Chem. A 1998, 102, 1995-2001; (b) Cossi, M.; Rega, N.; Scalmani, G.; Barone, V. J. Comput. Chem. 2003, 24, 669-681. 